\title{
Simulated nitrogen leaching, nitrogen mass field balances and their correlation on four farms in south-western Finland during the period 2000-2005
}

\author{
Katri Rankinen \\ Finnish Environment Institute, PO Box 140, FI-00251 Helsinki, Finland, e-mail: katri.rankinen@ymparisto.fi \\ Tapio Salo \\ MTT Agrifood Research Finland, FI-31600 Jokioinen, Finland \\ Kirsti Granlund \\ Finnish Environment Institute, PO Box 140, FI-00251 Helsinki, Finland \\ Hannu Rita \\ Department of Forest Resource Management, PO Box 27, FI-00014 University of Helsinki, Finland
}

\begin{abstract}
Nitrogen $(\mathrm{N})$ gross balance is one of the indicators designed for following developments in agriculture in the European Union. A nutrient surplus occurs when the quantity of a nutrient applied in fertilizers is greater than that removed during harvest. In this study the usefulness of $\mathrm{N}$ balance in studying the fate of $\mathrm{N}$ and controlling $\mathrm{N}$ leaching from agricultural fields in south-western Finland was evaluated. To estimate $\mathrm{N}$ leaching in 2000-2005 the mathematical, process-based model COUP was applied to twelve fields representing four agricultural production sectors. The fields represented conventional cereal production, organic cereal production and both conventional cattle and pig husbandry. Simulated N leaching was lowest from cereal production fields with a low $\mathrm{N}$ balance. Higher $\mathrm{N}$ leaching from pig and cattle production farms might be reduced by decreasing the $\mathrm{N}$ balance but also by applying manure in spring instead of autumn. Both $\mathrm{N}$ balance and simulated $\mathrm{N}$ leaching from organic farm were relatively high compared to low $\mathrm{N}$ application rate to the fields. $\mathrm{N}$ balance appears to be a rather useful indicator of $\mathrm{N}$ leaching over longer periods of time. In the short term, $\mathrm{N}$ leaching depends mainly on precipitation and on cultivation practices, like timing and amount of fertilizer application. Statistical evaluation indicated significant positive correlation between calculated $\mathrm{N}$ balance and simulated $\mathrm{N}$ leaching, especially when supported by constant values of precipitation and $\mathrm{N}$ mineralization rate. Decrease of $\mathrm{N}$ balance by $1 \mathrm{~kg} \mathrm{ha}^{-1} \mathrm{yr}^{-1}$ decreased $\mathrm{N}$ leaching by $0.3 \mathrm{~kg} \mathrm{ha}^{-1} \mathrm{yr}^{-1}$. High positive $\mathrm{N}$ balances are conducive to abundant accumulation of residual $\mathrm{N}$ in soil and consequently to a high risk of $\mathrm{N}$ leaching during rainy seasons.
\end{abstract}

Key words: agricultural production sectors, nitrogen balance, nitrogen leaching, process-based modelling, analysis of covariate 


\section{Introduction}

Leaching of nutrients into surface waters is one of the most persistent environmental problems of agriculture in Europe. In the Baltic Sea the key nutrient causing eutrophication is nitrogen $(\mathrm{N})$, whereas fresh waters and pristine parts of the Baltic Sea are more vulnerable to phosphorus (P) inputs (Pietiläinen and Räike 1999, Tamminen and Andersen 2007). During recent decades the rate of $\mathrm{N}$ input into the terrestrial $\mathrm{N}$ cycle has approximately doubled due to human activities (Vitousek et al. 1997), and the transfer of $\mathrm{N}$ through rivers to estuaries has greatly increased. The average share of agriculture in total loading of $\mathrm{N}$ and $\mathrm{P}$ to surface waters for the nine European Union (EU) member states with available data is $58 \%$ (European Environment Agency 2005).

The implementation of the EU Nitrates Directive in Finland is one of the policy measures aimed at decreasing $\mathrm{N}$ and $\mathrm{P}$ losses from agricultural sources (Mitikka et al. 2005). It contains provisions on good agricultural practices, storage of manure, spreading and allowable quantities of fertilizers and silage effluent and analysis and recording of $\mathrm{N}$ in fertilizers. It also sets the absolute, crop specific upper limits for $\mathrm{N}$ fertilizers. The most important policy measure for controlling agricultural $\mathrm{N}$ and $\mathrm{P}$ loading is the Finnish Agri-Environmental Program (AEP) (ValpasvuoJaatinen et al. 1997, Ministry of Agriculture and Forestry 2004a). In 2002 it covered about $92 \%$ of Finnish farms and $93 \%$ of the arable area (Ministry of Agriculture and Forestry 2004b). In general the maximum fertilization levels for different crops are lower in AEP than in the Nitrates Directive, with certain exceptions in cases when farmers are allowed to adjust $\mathrm{N}$ fertilization according to estimated yield.

In the AEP, environmental subsidy is paid to farmers who undertake 'basic' and 'additional measures', such as preparing a farm environmental management plan, establishing filter strips along main ditches and water courses and conforming to targeted levels of fertilizer and manure application. In animal husbandry reduction of ammonia emissions and treatment of dairy wastewater are supported. In turn, 'special measures' require more efficient environmental protection, e.g. establishment and management of $15 \mathrm{~m}$ wide buffer zones, wetlands and sedimentation ponds. Organic production belongs to special measures. Cereal production was the most common production line in Finland, accounting for 39\% of farms in 2003. Milk production and cattle husbandry was the main production line on $32 \%$ of farms. Pig husbandry was carried only on $5 \%$ of farms but it has been rapidly intensified in south-western Finland. In 2003 the percentage of farms carrying out organic farming was 7\% (Information Center of Agriculture and Forestry 2004).

Agri-environmental indicators are used to analyze the interactions between agriculture and the environment and the impact of changes in agricultural policy on the environment (European Environment Agency 2005). Indicators measure developments in selected issues and they can be used in follow-up studies of the measures required to reach or maintain the water quality status under European Union (EU) legislation, such as the Nitrates Directive and Agri-Environmental schemes.

Nitrogen gross balance at a national level is one of the indicators designed for following development and for estimating $\mathrm{N}$ surpluses in agriculture (OECD/EUROSTAT 2003). A condition of 'nutrient surplus' occurs when more nutrients in fertilizers and animal manure are applied to the land than are removed during harvest. Gross N balance has generally decreased in the EU between 1990 and 2000. At the EU level the gross $\mathrm{N}$ balance in 2000 was calculated to be $55 \mathrm{~kg} \mathrm{~N}^{-1}$, a $16 \%$ decrease from the level in 1990 (European Environment Agency 2005). In 2000 the national gross $\mathrm{N}$ balance in $\mathrm{EU}$ countries ranged from 37 $\mathrm{kg} \mathrm{N} \mathrm{ha}^{-1}$ to $226 \mathrm{~kg} \mathrm{~N} \mathrm{ha}^{-1}$, and in Finland it was around $50 \mathrm{~kg} \mathrm{~N}^{-1}$ (European Environment Agency 2005). National N balance has decreased in Finland since 1990 by $40 \mathrm{~kg} \mathrm{ha}^{-1}$ (Ministry of Agriculture and Forestry 2004, Salo et al. 2007). Although the national balance is at a reasonable level there may still be risk of $\mathrm{N}$ leaching at regional or local levels, for example in areas with high livestock densities (Oenema et al. 2003). 
There are three basic approaches in nutrient balance studies (Oenema et al. 2003). In the farmgate balance the amounts of nutrients in products entering or leaving the farm via the farm-gate are included. The difference between input and output is a measure of total nutrients adjusted for changes in the storage of the whole farming system. The field balance records all nutrients that enter the soil via the surface and leave the soil via crop uptake. The surplus (or deficit) is a measure of the total nutrient loss from the soil adjusted for changes in the storage of nutrients in the soil. The soil system balance records all nutrient inputs and outputs including nutrient gains and losses within and from the soil. Nutrient flows, nutrient cycling and changes in nutrient storages characterize soil system balance. A surplus (or deficit) is a measure of the net depletion or enrichment of the system.

Oenema et al. (2003) found a farm-gate balance to be most suitable as an environmental performance indicator. For example, Virtanen and Nousiainen (2005) associated farm-gate balance with selected dairy farm variables in Finland and concluded that nutrient surpluses could be controlled more easily in combined crop and milk production than in specialized milk production. A soil surface balance is appropriate for estimating the net loading of the soil with nutrient (Oenema et al. 2003). A field balance has been combined to $\mathrm{N}$ leaching in several studies, e.g. Korsaeth and Eltun (2000), Ulén et al. (2005) and Salo and Turtola (2006). The relationship between $\mathrm{N}$ balance and $\mathrm{N}$ leaching also depends very much on the cropping system, management practices, hydrological conditions and soil type and therefore $\mathrm{N}$ balance and $\mathrm{N}$ leaching are not necessarily well correlated (Lord et al. 2002, Oenema et al. 2005).

In this study the approach of a soil system balance was used to increase understanding of $\mathrm{N}$ inputs and outputs in fields under active cultivation according to current EU legislation. As a soil system balance takes into account $\mathrm{N}$ mineralization from soil organic matter and a change in inorganic $\mathrm{N}$ storage in soil it gives a better description of the fate of $\mathrm{N}$ than a simpler field $\mathrm{N}$ balance. The results are presented as field $\mathrm{N}$ balance, however, because thus they are comparable to existing statistical and field scale information. The mathematical, process-based model COUP (Coupled heat and mass transfer model for soil-plant-atmosphere systems) was applied to twelve fields representing four agricultural production sectors in order to evaluate changes in inorganic $\mathrm{N}$ storages and to estimate inorganic $\mathrm{N}$ leaching during the period 2000-2005. The main aims were to evaluate 1 ) the effect of different application rates of $\mathrm{N}$ fertilizers on the field $\mathrm{N}$ balance and $\mathrm{N}$ leaching, 2) the usefulness of the field $\mathrm{N}$ balance as an indicator of $\mathrm{N}$ leaching, and 3 ) the $\mathrm{N}$ leaching risks related to different production types.

\section{Materials and methods}

\section{Soil sampling from study fields}

Twelve fields from four farms located in the Yläneenjoki catchment in south-western Finland were selected for sampling soil inorganic N. The farms represented four different production systems: organic cereal, conventional cereal, conventional dairy cattle and conventional pig production. The Yläneenjoki catchment is one of the study catchments used for estimating environmental impacts of the AEP (e.g. Palva et al. 2001, Mattila et al. 2008). Since 1995, farms have been surveyed to collect annual information about agricultural practices. For example, all the 12 fields have well-functioning subsurface drainage. Further, no catch crop was grown on any of the fields.

In the Yläneenjoki catchment long-term mean annual precipitation is $700 \mathrm{~mm}$ and mean annual temperature $+4{ }^{\circ} \mathrm{C}$. The period 1999-2005 was warmer and dryer than the long term average so that the mean annual precipitation was $530 \mathrm{~mm}$ and mean annual temperature was $+5.1^{\circ} \mathrm{C}$.

The fields were sampled for total $\mathrm{N}$ and carbon (C), and soil particle size distribution (Table 1) from the soil layers $0-30,31-60$ and $61-80 \mathrm{~cm}$ in October 2000. Total $\mathrm{C}$ and $\mathrm{N}$ were analysed with 
Rankinen, K. et al. Modelled farm-based nitrogen leaching and nitrogen balance in 2000-2005

Table 1. Total carbon (C) and nitrogen (N) contents and particle size distribution in fields (average for 0-30 $\mathrm{cm}$ depth).

\begin{tabular}{|c|c|c|c|c|c|c|c|c|}
\hline \multirow[b]{2}{*}{ Production type } & \multirow[b]{2}{*}{ Field nro. } & \multicolumn{2}{|c|}{ Total nutrients } & \multicolumn{5}{|c|}{ Particle size (\%) } \\
\hline & & $\begin{array}{l}\mathrm{N} \\
(\%)\end{array}$ & $\begin{array}{l}\mathrm{C} \\
(\%)\end{array}$ & $\begin{array}{c}<0.002 \\
(\mathrm{~mm})\end{array}$ & $\begin{array}{c}0.002-0.02 \\
(\mathrm{~mm})\end{array}$ & $\begin{array}{c}0.02-0.2 \\
(\mathrm{~mm})\end{array}$ & $\begin{array}{c}0.2-2.0 \\
(\mathrm{~mm})\end{array}$ & $\begin{array}{l}>2.0 \\
(\mathrm{~mm})\end{array}$ \\
\hline Conventional cereal & Field 1 & 0.19 & 3.03 & 25 & 39 & 34 & 3 & 0 \\
\hline Conventional cereal & Field 2 & 0.13 & 1.75 & 21 & 31 & 46 & 3 & 0 \\
\hline Conventional cereal & Field 3 & 0.16 & 2.55 & 21 & 36 & 42 & 2 & 0 \\
\hline Organic cereal & Field 4 & 0.14 & 2.39 & 19 & 21 & 57 & 3 & 0 \\
\hline Organic cereal & Field 5 & 0.18 & 2.69 & 26 & 25 & 44 & 5 & 0 \\
\hline Organic cereal & Field 6 & 0.19 & 3.03 & 9 & 27 & 62 & 3 & 0 \\
\hline Cattle husbandry & Field 7 & 0.30 & 4.58 & 24 & 35 & 34 & 7 & 0 \\
\hline Cattle husbandry & Field 8 & 0.24 & 3.79 & 69 & 14 & 12 & 5 & 0 \\
\hline Cattle husbandry & Field 9 & 0.39 & 6.74 & 67 & 20 & 10 & 3 & 0 \\
\hline Pig husbandry & Field 10 & 0.18 & 3.30 & 11 & 42 & 43 & 3 & 0 \\
\hline Pig husbandry & Field 11 & 0.13 & 1.54 & 26 & 30 & 41 & 3 & 0 \\
\hline Pig husbandry & Field 12 & 0.15 & 2.22 & 36 & 26 & 36 & 3 & 0 \\
\hline
\end{tabular}

a LECO-analyser and particle size distribution by the pipette method.

Soil inorganic $\mathrm{N}$ was sampled from the same soil layers in Octobers of 2000-2005. Ten subsamples from the 0-30 and 31-60 soil layers and five sub-samples from the $61-80 \mathrm{~cm}$ soil layer were collected and integrated for each field. Soil inorganic $\mathrm{N}$ was extracted with $2 \mathrm{M} \mathrm{KCl}$ and analyzed with a Lachat AutoAnalyser for $\mathrm{NH}_{4}-\mathrm{N}$ and $\mathrm{NO}_{3}-\mathrm{N}$. The dry matter content of the soil was determined by drying $40 \mathrm{~g}$ moist soil overnight at $105^{\circ} \mathrm{C}$. If soil inorganic $\mathrm{N}$ averaged over three sampled layers was above $5 \mathrm{mg} \mathrm{kg}^{-1}$ soil in autumn, soil inorganic $\mathrm{N}$ was also sampled in the following spring. Soil bulk density of the $0-30$ soil layer was sampled from the fields in October 2006 in order to calculate results on the $\mathrm{kg} \mathrm{ha}^{-1}$ basis.

\section{Field $\mathrm{N}$ balance}

Data concerning field management practices was either asked directly or collected from the AEP interview data. The data included the following field management information: crop (sowing date, harvest date, yield level), use of fertilizers (date, type, amount) and soil tillage (date and depth of till- age). Nutrient concentrations of the fertilizers were provided by the manufacturer Kemira GrowHow and $\mathrm{N}$ concentration of manure was available as average manure $\mathrm{N}$ concentrations in the statistical data (Viljavuuspalvelu 2000). Selected information is presented in Tables 2 and 3.

Amounts of fertilizers applied on fields in autumns are presented in Table 4. On the conventional cereal farm only mineral fertilizers were used. Green manure was used in organic cereal farming but also on the cattle farm. Simulated values for $\mathrm{N}$ fixing are presented in Table 5. Manure was applied in autumn, especially on the pig farm but also on the cattle farm. Small amounts of N (about $30 \mathrm{~kg}$ $\mathrm{N} \mathrm{ha}^{-1}$ ) were applied only for winter crops in the organic farm and the cereal farm in autumn.

$\mathrm{N}$ balance was calculated as $\mathrm{N}$ input (fertilizer $\mathrm{N}$, manure $\mathrm{N}$ and $\mathrm{N}$ fixation) minus harvest of $\mathrm{N}$. Gaseous losses of $\mathrm{N}$ as denitrification or ammonia volatilization from manure were not estimated as outputs in the $\mathrm{N}$ balance calculations. Crop $\mathrm{N}$ uptake was based on yield level, and inputs of fertilizer $\mathrm{N}$ and manure $\mathrm{N}$ were based on interview data. In the balance calculations, fixation of different crops was based on available data and used further as target $\mathrm{N}$ fixation when calibrating the model for the simulations. 
Vol. 16 (2007): 387-406

Table 2. Crop and fertilization information in different fields of conventional and organic crop production. A given period is always from autumn to the next autumn.

\begin{tabular}{|c|c|c|c|c|c|c|}
\hline & $\begin{array}{c}\text { Period } 1 \\
\text { 1999-2000 }\end{array}$ & $\begin{array}{c}\text { Period } 2 \\
2000-2001\end{array}$ & $\begin{array}{c}\text { Period } 3 \\
2001-2002\end{array}$ & $\begin{array}{c}\text { Period } 4 \\
2002-2003\end{array}$ & $\begin{array}{c}\text { Period 5 } \\
2003-2004\end{array}$ & $\begin{array}{c}\text { Period } 6 \\
2004-2005\end{array}$ \\
\hline \multicolumn{7}{|c|}{ Conventional cereal production } \\
\hline \multicolumn{7}{|c|}{ Field 1} \\
\hline Crop & Spring wheat & Spring wheat & Winter wheat & Spring wheat & Barley & Spring wheat \\
\hline Fertilization $\left(\mathrm{kg} \mathrm{N} \mathrm{ha}^{-1}\right)$ & 100 & 88 & 153 & 100 & 77 & 96 \\
\hline Manure $\left(\mathrm{kg} \mathrm{N} \mathrm{ha}^{-1}\right)$ & 0 & 0 & 0 & 0 & 0 & 0 \\
\hline Yield $\left(\mathrm{kg} \mathrm{ha}^{-1}\right)$ & 3900 & 5100 & 5100 & 4300 & 4700 & 4400 \\
\hline \multicolumn{7}{|l|}{ Field 2} \\
\hline Crop & Barley & Barley & Turnip rape & Winter wheat & Spring wheat & Barley \\
\hline Fertilization $\left(\mathrm{kg} \mathrm{N} \mathrm{ha}^{-1}\right)$ & 84 & 84 & 125 & 153 & 104 & 96 \\
\hline Manure $\left(\mathrm{kg} \mathrm{N} \mathrm{ha}^{-1}\right)$ & 0 & 0 & 0 & 0 & 0 & 0 \\
\hline Yield $\left(\mathrm{kg} \mathrm{ha}^{-1}\right)$ & 5200 & 5200 & 2300 & 5000 & 4900 & 4300 \\
\hline \multicolumn{7}{|l|}{ Field 3} \\
\hline Crop & Winter wheat & Spring wheat & Spring wheat & Barley & Winter wheat & Spring wheat \\
\hline Fertilization $\left(\mathrm{kg} \mathrm{N} \mathrm{ha}^{-1}\right)$ & 180 & 116 & 112 & 74 & 153 & 97 \\
\hline Manure $\left(\mathrm{kg} \mathrm{N} \mathrm{ha}^{-1}\right)$ & 0 & 0 & 0 & 0 & 0 & 0 \\
\hline Yield $\left(\mathrm{kg} \mathrm{ha}^{-1}\right)$ & 4200 & 4200 & 3500 & 4000 & 5400 & 4700 \\
\hline \multicolumn{7}{|l|}{ Organic cereal production } \\
\hline \multicolumn{7}{|l|}{ Field 4} \\
\hline Crop & Field pea & Spring rye & Spring rye & Turnip rape & $\begin{array}{c}\text { Turnip } \\
\text { rape+clover }\end{array}$ & Clover grass \\
\hline Fertilization $\left(\mathrm{kg} \mathrm{N} \mathrm{ha}^{-1}\right)$ & 0 & 0 & 0 & 0 & 0 & 0 \\
\hline Manure $\left(\mathrm{kg} \mathrm{N} \mathrm{ha}^{-1}\right)$ & 0 & 49 & 54 & 66 & 4.1 & 41.4 \\
\hline Yield $\left(\mathrm{kg} \mathrm{ha}^{-1}\right)$ & 1500 & 1500 & 1500 & 200 & 1000 & - \\
\hline \multicolumn{7}{|l|}{ Field 5} \\
\hline Crop & Spring rye & Open fallow & Winter rye & Green Fallow & Spelt & Spring rye \\
\hline Fertilization $\left(\mathrm{kg} \mathrm{N} \mathrm{ha}^{-1}\right)$ & 0 & 0 & 0 & 0 & 0 & 0 \\
\hline Manure $\left(\mathrm{kg} \mathrm{N} \mathrm{ha}^{-1}\right)$ & 49 & 55 & 0 & 0 & 62 & 33 \\
\hline Yield $\left(\mathrm{kg} \mathrm{ha}^{-1}\right)$ & 1000 & - & 1200 & - & 2000 & 1100 \\
\hline \multicolumn{7}{|l|}{ Field 6} \\
\hline Crop & Spring wheat & Field pea & Spring wheat & Turnip rape & Fallow & Rye \\
\hline Fertilization $\left(\mathrm{kg} \mathrm{N} \mathrm{ha}^{-1}\right)$ & 0 & 0 & 0 & 0 & 0 & 0 \\
\hline Manure $\left(\mathrm{kg} \mathrm{N} \mathrm{ha}^{-1}\right)$ & 79 & 0 & 54 & 66 & 98 & 46 \\
\hline Yield $\left(\mathrm{kg} \mathrm{ha}^{-1}\right)$ & 1500 & 0 & 2800 & 200 & - & 1500 \\
\hline
\end{tabular}

\section{The COUP model set-up}

The mathematical model COUP (Coupled heat and mass transfer model for soil-plant-atmosphere system) is a dynamic, process-based model to calculate water and heat fluxes and $\mathrm{C}$ and $\mathrm{N}$ cycles in the soil profile (Jansson and Karlberg 2001). The model is commonly used in the Nordic countries for modeling hydrological processes and inorganic $\mathrm{N}$ leaching from agricultural soils (Kallio et al. 1997, Arheimer and Brandt 2000, Granlund et al. 2000, Kyllmar 2004).
The basic structure of the model is a depth profile of the soil. The soil profile can be divided into layers based on soil properties. Two coupled differential equations for water (Darcy's law) and heat flow (Fourier's law) comprise the central part of the model. Dynamics of snow, soil frost, evaporation, infiltration, surface runoff and runoff through soil layers are described in the hydrological cycle.

The major $\mathrm{N}$ and $\mathrm{C}$ components of a soil-plant system can be considered. Nitrogen enters the soil either as external inputs, i.e. manure, biological 
Rankinen, K. et al. Modelled farm-based nitrogen leaching and nitrogen balance in 2000-2005

Table 3. Crop and fertilization information in the fields of animal husbandry farms. A period is always from autumn to the next autumn.

\begin{tabular}{|c|c|c|c|c|c|c|}
\hline & $\begin{array}{c}\text { Period } 1 \\
\text { 1999-2000 }\end{array}$ & $\begin{array}{c}\text { Period } 2 \\
2000-2001\end{array}$ & $\begin{array}{c}\text { Period 3 } \\
2001-2002\end{array}$ & $\begin{array}{c}\text { Period } 4 \\
2002-2003\end{array}$ & $\begin{array}{c}\text { Period 5 } \\
2003-2004\end{array}$ & $\begin{array}{c}\text { Period } 6 \\
2004-2005\end{array}$ \\
\hline \multicolumn{7}{|l|}{ Cattle husbandry } \\
\hline \multicolumn{7}{|l|}{ Field 7} \\
\hline Crop & Grass ley & Grass ley & Fallow & Winter wheat & Winter wheat & Fallow \\
\hline Fertilization $\left(\mathrm{kg} \mathrm{N} \mathrm{ha}^{-1}\right)$ & 227 & 217 & 0 & 134 & 140 & 0 \\
\hline Manure $\left(\mathrm{kg} \mathrm{N} \mathrm{ha}^{-1}\right)$ & 0 & 0 & 0 & 66 & 0 & 0 \\
\hline Yield $\left(\mathrm{kg} \mathrm{ha}^{-1}\right)$ & 42800 & 25640 & - & 4500 & 6260 & - \\
\hline \multicolumn{7}{|l|}{ Field 8} \\
\hline Crop & Grass ley & Barley & Oat & Spring wheat & Barley & Grass ley \\
\hline Fertilization $\left(\mathrm{kg} \mathrm{N} \mathrm{ha}^{-1}\right)$ & 215 & 77 & 61 & 111 & 68 & 211 \\
\hline Manure $\left(\mathrm{kg} \mathrm{N} \mathrm{ha}^{-1}\right)$ & 0 & 66 & 109 & 66 & 0 & 0 \\
\hline Yield $\left(\mathrm{kg} \mathrm{ha}^{-1}\right)$ & 42000 & 5400 & 5000 & 5200 & 5500 & 11200 \\
\hline \multicolumn{7}{|l|}{ Field 9} \\
\hline Crop & Oat & Barley & Barley & Garden pea & Winter wheat & Barley \\
\hline Fertilization $\left(\mathrm{kg} \mathrm{N} \mathrm{ha}^{-1}\right)$ & 41 & 66 & 66 & 26 & 110 & 50 \\
\hline Manure $\left(\mathrm{kg} \mathrm{N} \mathrm{ha}^{-1}\right)$ & 99 & 99 & 92 & 66 & 0 & 90 \\
\hline Yield $\left(\mathrm{kg} \mathrm{ha}^{-1}\right)$ & 3500 & 5000 & 6000 & 5040 & 5000 & 6500 \\
\hline \multicolumn{7}{|l|}{ Pig husbandry } \\
\hline \multicolumn{7}{|l|}{ Field 10} \\
\hline Crop & Oat & Oat & Barley & Winter wheat & Barley & Barley \\
\hline Fertilization $\left(\mathrm{kg} \mathrm{N} \mathrm{ha}^{-1}\right)$ & 110 & 110 & 135 & 109 & 110 & 102 \\
\hline Manure $\left(\mathrm{kg} \mathrm{N} \mathrm{ha}^{-1}\right)$ & 0 & 0 & 0 & 0 & 0 & 0 \\
\hline Yield $\left(\mathrm{kg} \mathrm{ha}^{-1}\right)$ & 4500 & 5000 & 3800 & 3600 & 4500 & 3800 \\
\hline \multicolumn{7}{|l|}{ Field 11} \\
\hline Crop & Winter wheat & Winter wheat & Barley & Winter wheat & Winter wheat & Barley \\
\hline Fertilization $\left(\mathrm{kg} \mathrm{N} \mathrm{ha}^{-1}\right)$ & 91 & 60 & 57 & 104 & 83 & 91 \\
\hline Manure $\left(\mathrm{kg} \mathrm{N} \mathrm{ha}^{-1}\right)$ & 84 & 88 & 76 & 174 & 68 & 0 \\
\hline Yield $\left(\mathrm{kg} \mathrm{ha}^{-1}\right)$ & 4200 & 3500 & 3500 & 4000 & 3500 & 4000 \\
\hline \multicolumn{7}{|l|}{ Field 12} \\
\hline Crop & Barley & Barley & Barley & Barley & Winter wheat & Barley \\
\hline Fertilization $\left(\mathrm{kg} \mathrm{N} \mathrm{ha}^{-1}\right)$ & 50 & 26 & 23 & 42 & 50 & 38 \\
\hline Manure $\left(\mathrm{kg} \mathrm{N} \mathrm{ha}^{-1}\right)$ & 104 & 65 & 95 & 96 & 226 & 147 \\
\hline Yield $\left(\mathrm{kg} \mathrm{ha}^{-1}\right)$ & 4000 & 4500 & 3800 & 4500 & 4500 & 4000 \\
\hline
\end{tabular}

$\mathrm{N}$ fixation, deposition and fertilization, or from the plant litter fall. In the soil there are three organic pools (faeces, litter and humus) and two inorganic nitrogen pools $\left(\mathrm{NH}_{4}^{+}-\mathrm{N}\right.$ and $\left.\mathrm{NO}_{3}^{-}-\mathrm{N}\right)$. Decomposition of $\mathrm{C}$ affects the $\mathrm{C} / \mathrm{N}$ ratio of soil and is a driving force for immobilization/mineralization of $\mathrm{N}$ and further nitrification. Plants take up inorganic $\mathrm{N}$ during growth. The plant may be harvested at the end of the growing season. Denitrification and leaching also remove $\mathrm{N}$ from the soil system.

Daily mean temperature $\left({ }^{\circ} \mathrm{C}\right)$, relative humidity $(\%)$, wind speed $\left(\mathrm{m} \mathrm{s}^{-1}\right)$, precipitation $(\mathrm{mm})$, duration of bright sunshine and radiation net input $\left(\mathrm{kJ} \mathrm{m}^{-2}\right)$ from the Jokioinen Observatory of Finnish Meteorological Institute were available as meteorological input data. Monthly precipitation and temperature are presented in Tables 6 and 7.

The model set-up to the fields was based on measured physical and chemical soil properties. The water retention curve was estimated on the basis of particle size distribution. Plant growth was based on time series of typical development for leaf area index and canopy height of different crops. The hydrological year (from autumn to 
Vol. 16 (2007): 387-406

Table 4. Autumn spreading of mineral fertilizers and manure in fields of cattle and pig production.

\begin{tabular}{llllc}
\hline Farm & Field & Year & Type & $\begin{array}{c}\text { Tot-N applied } \\
\left(\mathrm{kg} \mathrm{ha}^{-1}\right)\end{array}$ \\
\hline Cattle production & Field 7 & 2003 & Cattle slurry & 66 \\
& Field 8 & 2000 & Cattle slurry & 66 \\
& & 2002 & Cattle slurry & 66 \\
& Field 9 & 2003 & Cattle slurry & 66 \\
Pig production & 2004 & Cattle slurry & 66 \\
& Field 10 & 2002 & Mineral fertilizer & 30 \\
& Field 11 & 1999 & Pig slurry & 84 \\
& & Pig slurry & 88 \\
& & 2000 & Pig urine & 67 \\
& & 2002 & Pig urine & 42 \\
& & Mineral fertilizer & 26 \\
& & 2003 & Pig urine & 65 \\
& & 2000 & Pig urine & 47 \\
& & 2003 & Pig slurry & 76 \\
& & 2003 & Pig urine & 53 \\
\hline
\end{tabular}

autumn) was modelled to cover the crop rotation including winter cereals. Agricultural measures were based on interview data. Inorganic $\mathrm{N}$ concentrations in soil from the previous year were used as initial values in the following year, and each year were calibrated separately. Simulated inorganic N concentrations in soil layers $(0-30,31-60,61-80$ $\mathrm{cm})$ were calibrated against measured values $(+/-10 \%)$ by changing mineralization rates in soil. As mineralization rates were not measured in the field, default values of the COUP model were changed according to measured rates in study fields of MTT Agrifood Research Finland with corresponding soil type and climate (Rankinen et al. 2006). Biological $\mathrm{N}$ fixation was calibrated against values used in the field $\mathrm{N}$ balance. Nutrient uptake of different crops was calibrated against statistics of crop yields and by comparing simulated $\mathrm{N}$ and $\mathrm{C}$ contents in roots, stems and leaves separately to values found in the literature, so that uptake of the yields reached the value used in calculating field $\mathrm{N}$ balances. Different manure types were assumed to decay at the same rate.

\section{Scenarios of crop uptake and fertilization levels}

When following additional measures of the AEP, farmers were allowed to adjust $\mathrm{N}$ fertilization

Table 5. Simulated N fixation on fields of organic crop production and cattle production.

\begin{tabular}{llllr}
\hline Farm & Field & Year & Crop & $\begin{array}{c}\text { Tot-N } \\
\left(\mathrm{kg} \mathrm{ha}^{-1}\right)\end{array}$ \\
\hline Organic crop production & Field 4 & 2000 & Field pea & 68 \\
& & 2004 & Clover grass & 204 \\
Cattle production & & 2005 & Clover grass & 65 \\
\hline
\end{tabular}


according to estimated yield instead of limiting fertilization according to the targeted levels of 'basic measures'. This additional measure has led farmers to make optimistic yield estimates, which allow increased $\mathrm{N}$ fertilization levels (Pyykkönen et al. 2004). To assess the impact of the yield estimate on $\mathrm{N}$ balance and $\mathrm{N}$ leaching a scenario of crop uptake was run for the conventional cereal production farm and the pig production farm. In this scenario crop uptake was assumed to be $20 \%$ lower than in the base scenario (farmers' interview information).

Two scenarios of $\mathrm{N}$ balance were run for the conventional cereal production farm to evaluate different application rates of $\mathrm{N}$ fertilizers on field $\mathrm{N}$ balance and $\mathrm{N}$ leaching. In the first scenario fertilization (mineral + manure) was increased by $20 \%$ and in the second scenario fertilization was decreased by $20 \%$. The same scenarios were run for the pig production farm, together with an additional third scenario for one field. In this third scenario manure application in autumn was omitted and the same amount of manure as in the base case was applied only in spring to see how much leaching can be reduced only by changing timing of spreading.

\section{Statistical analysis}

Simple regression analysis was used to measure the relationship between $\mathrm{N}$ leaching and field $\mathrm{N}$ balance or precipitation. One-way ANOVA was used to analyze whether $\mathrm{N}$ balance averages differed in the three different fertilization scenarios as well as whether $\mathrm{N}$ leaching averages differed in the various crop uptake scenarios.

The effect of field $\mathrm{N}$ balance on $\mathrm{N}$ leaching was studied using analysis of covariance (ANCOVA). As precipitation, $\mathrm{N}$ mineralization rate, $\mathrm{N}$ fertilization and $\mathrm{N}$ uptake are known to correlate with $\mathrm{N}$ leaching, they were used as covariates. To overcome the problem of correlations between these CDUs, the elaboration technique was used (Babbie 1975). In it the CDUs are included into the ANCOVA model cumulatively and changes in the coefficient of $\mathrm{N}$ balance are recorded and interpreted. For an application of the approach see Apetroaie-Constantin et al. (2007). As ANCOVA assumes homogeneity of regression slopes, it could not be used for organic and pig farms. No statistical analyses were conducted for the scenario of 'autumn application of manure'.

\section{Results}

\section{$\mathrm{N}$ balance in different crop production systems}

Simulated and measured inorganic $\mathrm{N}$ contents in the soil layer $0-80 \mathrm{~cm}$ are presented in Fig. 1-4. Measured inorganic $\mathrm{N}$ concentrations were highest in fields of cattle and pig farms, where manure was applied on fields regularly. The lowest inorganic $\mathrm{N}$ concentrations in general were measured in fields of the organic farm, where no commercial fertilizer and only small amounts of manure were applied annually.

Average $\mathrm{N}$ field balance was positive on all the fields. On the fields of the pig farm $\mathrm{N}$ balance was highest, on an average $62 \mathrm{~kg} \mathrm{~N} \mathrm{ha}^{-1} \mathrm{yr}^{-1}$ with standard deviation (S.D.) $39 \mathrm{~kg} \mathrm{~N} \mathrm{ha}^{-1} \mathrm{yr}^{-1}$. On the cattle farm the average $\mathrm{N}$ balance was $44 \mathrm{~kg} \mathrm{~N} \mathrm{ha}^{-1} \mathrm{yr}^{-1}$ (S.D. $47 \mathrm{~kg} \mathrm{~N} \mathrm{ha}^{-1} \mathrm{yr}^{-1}$ ) and in cereal production 32 kg N ha ${ }^{-1} \mathrm{yr}^{-1}$ (S.D. $26 \mathrm{~kg} \mathrm{~N}^{-1} \mathrm{hr}^{-1}$ ). Average $\mathrm{N}$ balance in organic production was $27 \mathrm{~kg} \mathrm{~N} \mathrm{ha}^{-1} \mathrm{yr}^{-1}$ (S.D. $53 \mathrm{~kg} \mathrm{~N} \mathrm{ha}^{-1} \mathrm{yr}^{-1}$ ).

On the fields of the pig farm the simulated average leaching was $48 \mathrm{~kg} \mathrm{~N} \mathrm{ha}^{-1} \mathrm{yr}^{-1}$. On the cattle farm the average simulated $\mathrm{N}$ leaching was $26 \mathrm{~kg}$ $\mathrm{N} \mathrm{ha}{ }^{-1} \mathrm{yr}^{-1}$. N leaching was $38 \mathrm{~kg} \mathrm{~N} \mathrm{ha}^{-1} \mathrm{yr}^{-1}$ and $39 \mathrm{~kg} \mathrm{~N} \mathrm{ha}^{-1} \mathrm{yr}^{-1}$ from the conventional cereal farm and the organic cereal farm, respectively. Simulated $\mathrm{N}$ mineralization in soil varied between $55 \mathrm{~kg}$ $\mathrm{N} \mathrm{ha} \mathrm{yr}^{-1} \mathrm{yr}^{-1}$ on the organic farm and $40 \mathrm{~kg}$ $\mathrm{N} \mathrm{ha}{ }^{-1} \mathrm{yr}^{-1}$ on the pig farm. On the conventional cereal farm simulated $\mathrm{N}$ mineralization in soil was $44 \mathrm{~kg} \mathrm{~N} \mathrm{ha}^{-1} \mathrm{yr}^{-1}$ and on the cattle farm $52 \mathrm{~kg}$ $\mathrm{N} \mathrm{ha}^{-1} \mathrm{yr}^{-1}$.

There was no correlation (Kendall Tau b) between $\mathrm{N}$ balance and simulated $\mathrm{N}$ leaching on 
Vol. 16 (2007): 387-406

Field 1

Inorganic $\mathrm{N}\left(\mathrm{g} \mathrm{m}^{-2}\right)$

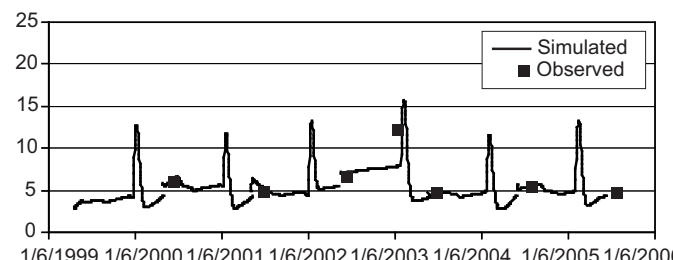

1/6/1999 1/6/2000 1/6/2001 1/6/20021/6/2003 1/6/2004 1/6/2005 1/6/2006

Field 2

Inorganic $\mathrm{N}\left(\mathrm{g} \mathrm{m}^{-2}\right)$

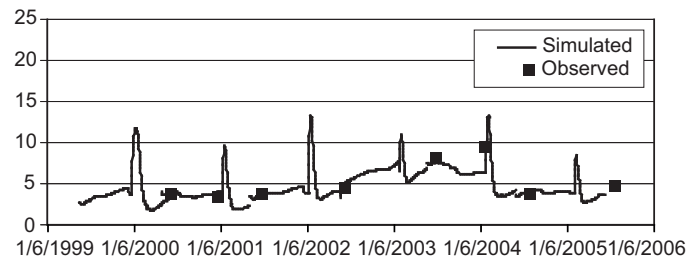

Field 3

Inorganic $\mathrm{N}\left(\mathrm{g} \mathrm{m}^{-2}\right)$

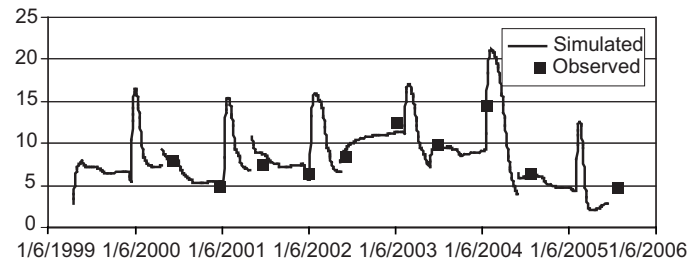

Fig.1. Simulated and observed inorganic N content in $0-80 \mathrm{~cm}$ soil profile in fields of the conventional cereal production farm.

the farm level when results from all three fields of the farm were included. Positive correlation was found between precipitation and simulated $\mathrm{N}$ leaching. Correlation between precipitation and simulated $\mathrm{N}$ leaching was significant on the conventional cereal production and pig farms (Fig. 5), on which the standard deviations of annual $\mathrm{N}$ balances were lowest.

Simulated N leaching from different fields varied between the years depending on both precipitation and cultivation practices. Lowest leaching from most of the fields was simulated in period 4, which covered autumn 2002 and spring 2003 when precipitation was very low (Table 6). Highest leaching on average was simulated during the following rainy summer period. Highest occasional leaching, $195 \mathrm{~kg} \mathrm{~N} \mathrm{ha}^{-1} \mathrm{yr}^{-1}$, was simulated from
Field 4

Inorganic N $\left(\mathrm{g} \mathrm{m}^{-2}\right)$

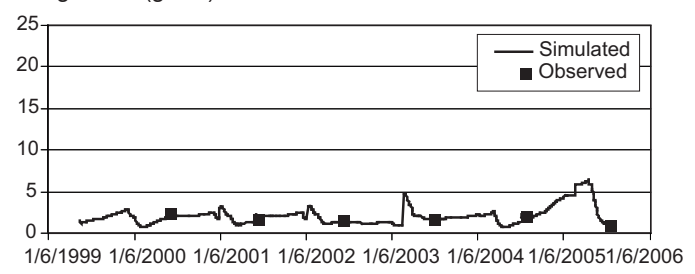

Field 5

Inorganic $\mathrm{N}\left(\mathrm{g} \mathrm{m}^{-2}\right)$

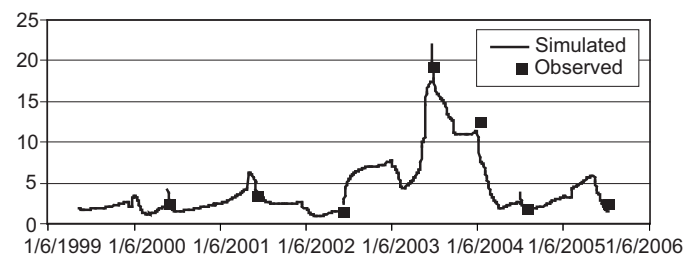

Field 6

Inorganic $\mathrm{N}\left(\mathrm{g} \mathrm{m}^{-2}\right)$

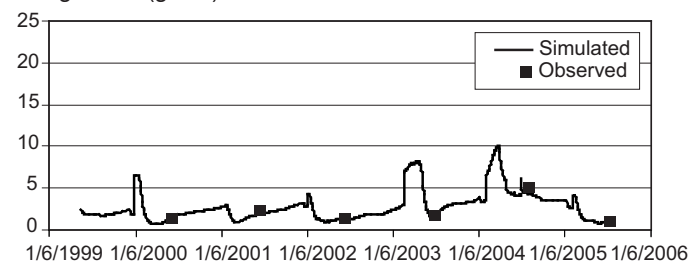

Fig. 2. Simulated and observed inorganic $\mathrm{N}$ content in $0-80 \mathrm{~cm}$ soil profile in fields of the organic cereal production farm.

Field 5 on the organic cereal farm where inorganic $\mathrm{N}$ had accumulated in soil after green fallow in the growing season of 2003 (Fig. 6). Accumulated N was washed away during the following autumn/ winter but also during the following growing season when crop uptake was relatively low.

Statistically significant correlation (negative) between $\mathrm{N}$ balance and $\mathrm{N}$ leaching on the field level was found only on Field 9 on the cattle farm (Fig. 6). On that field $\mathrm{N}$ balance was relatively high (around $80 \mathrm{~kg} \mathrm{ha}^{-1}$ ) in the years 2000-2002. The main crops were spring cereals, and both manure and mineral fertilizers were applied in spring. Nitrogen balance was even higher $(>120$ $\mathrm{kg} \mathrm{ha}^{-1}$ ) in 2003 when the main crop was garden pea and mineral fertilizer was applied in spring and manure in autumn. In the rainy years 2004 and 2005 
Field 7

Inorganic $\mathrm{N}\left(\mathrm{g} \mathrm{m}^{-2}\right)$

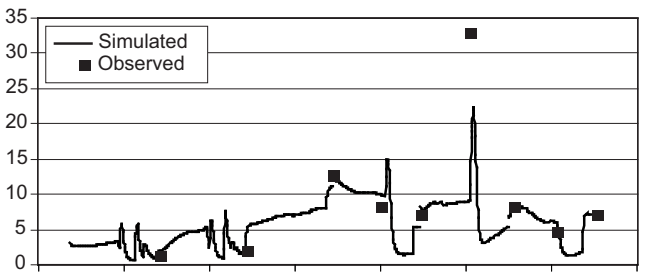

1/6/1999 1/6/2000 1/6/2001 1/6/2002 1/6/2003 1/6/2004 1/6/2005 1/6/2006

Field 8

Inorganic $\mathrm{N}\left(\mathrm{g} \mathrm{m}^{-2}\right)$

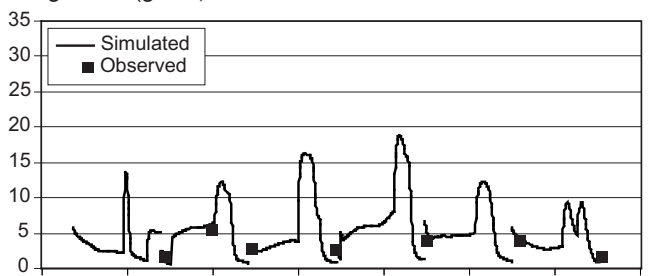

1/6/1999 1/6/2000 1/6/2001 1/6/2002 1/6/2003 1/6/2004 1/6/2005 1/6/2006

Field 9

Inorganic $\mathrm{N}\left(\mathrm{g} \mathrm{m}^{-2}\right)$

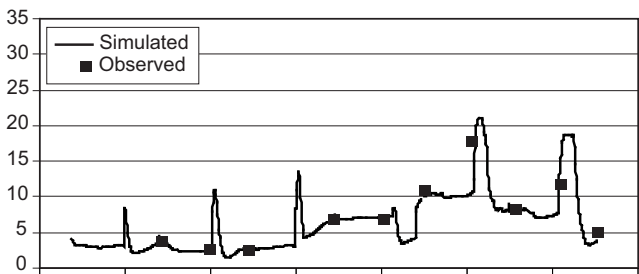

1/6/1999 1/6/2000 1/6/2001 1/6/2002 1/6/2003 1/6/2004 1/6/2005 1/6/2006

Fig. 3. Simulated and observed inorganic $\mathrm{N}$ content in $0-80 \mathrm{~cm}$ soil profile in fields of the cattle production farm.

$\mathrm{N}$ balances were lower (24 and $41 \mathrm{~kg} \mathrm{ha}^{-1}$ ), but accumulated inorganic $\mathrm{N}$ was washed away from soil, giving rise to high $\mathrm{N}$ leaching.

In all fields simulated $\mathrm{N}$ leaching peaked in the period between harvest and soil frost in late autumn. When the year was divided into two equal parts, the non-growing season from autumn to spring accounted for 40-98\% of simulated annual leaching. This was not only accumulated $\mathrm{N}$ from fertilizers but also because of high $\mathrm{N}$ mineralization in soils in autumn (Fig. 7), when temperatures were still high enough for mineralization of organic matter (Table 7).
Field 10

Inorganic $\mathrm{N}\left(\mathrm{g} \mathrm{m}^{-2}\right)$

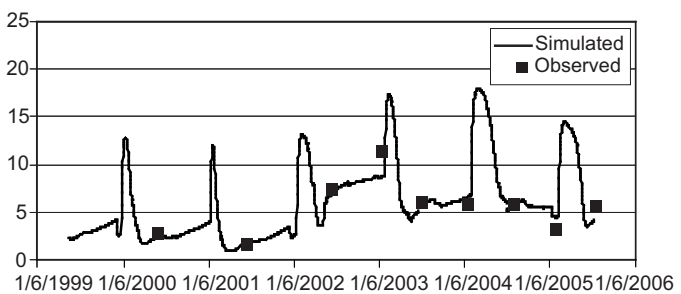

Field 11

Inorganic $\mathrm{N}\left(\mathrm{g} \mathrm{m}^{-2}\right)$

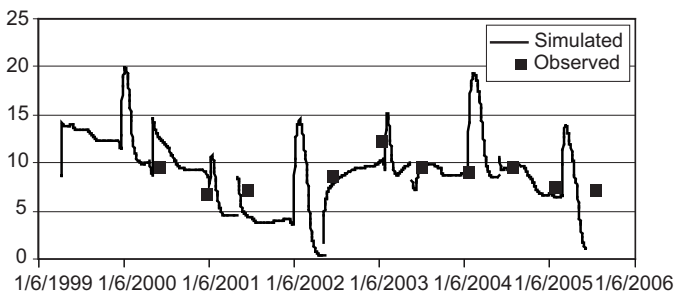

Field 12

Inorganic $\mathrm{N}\left(\mathrm{g} \mathrm{m}^{-2}\right)$

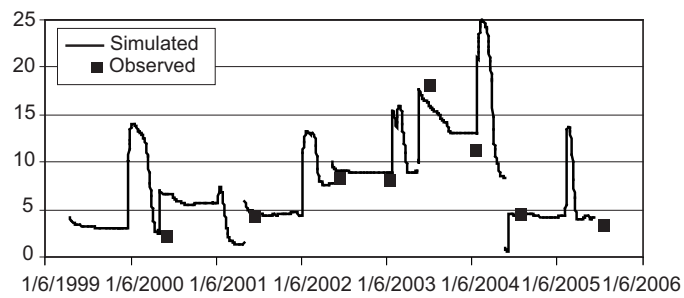

Fig. 4. Simulated and observed inorganic $\mathrm{N}$ content in $0-80 \mathrm{~cm}$ soil profile in fields of the pig production farm.

\section{Scenario of crop uptake}

A decrease in crop uptake of $20 \%$ increased the $\mathrm{N}$ balance by about $10-15 \mathrm{~kg} \mathrm{ha}^{-1}$ but changed $\mathrm{N}$ leaching less than $5 \mathrm{~kg} \mathrm{ha}^{-1}$. Percentage increase for $\mathrm{N}$ balance was considerable $(30-50 \%)$. The percentage change (positive or negative) in $\mathrm{N}$ leaching was less than $10 \%$. ANOVA could not indentify any statistically significant difference in $\mathrm{N}$ leaching between the base scenario and the scenario of lower crop $\mathrm{N}$ uptake, but increase in $\mathrm{N}$ balance was statistically significant. The correlation between $\mathrm{N}$ balance and $\mathrm{N}$ leaching did not change (Fig. 8). 
Vol. 16 (2007): 387-406

\section{Conventional cereal production}

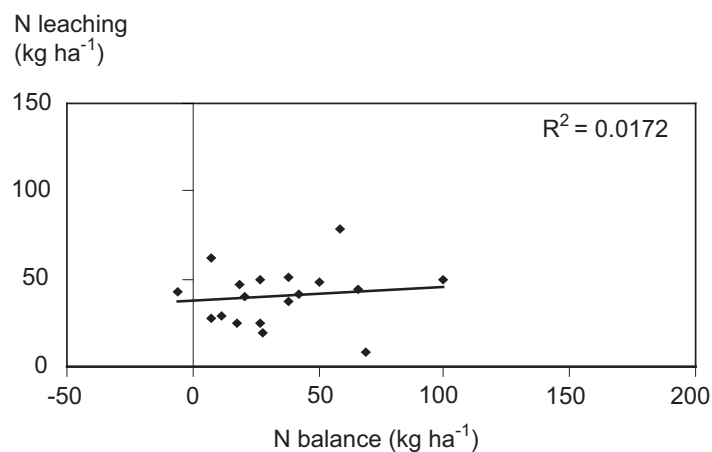

Pig husbandry production

$\mathrm{N}$ leaching

(kg ha ${ }^{-1}$ )

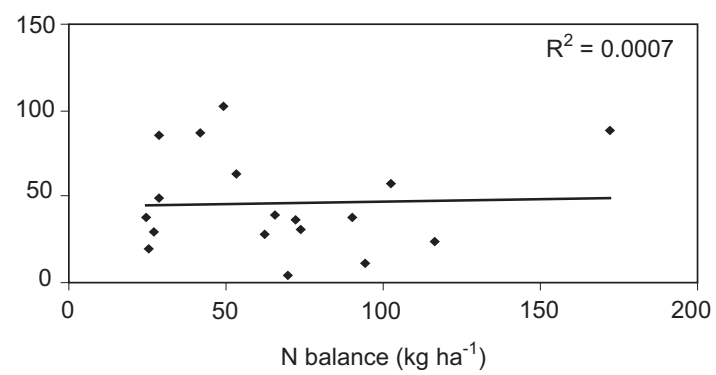

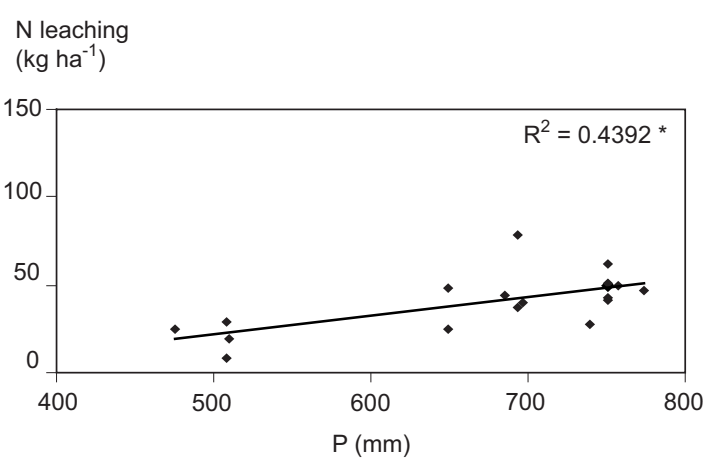

$\mathrm{N}$ leaching $\left(\mathrm{kg} \mathrm{ha}^{-1}\right)$

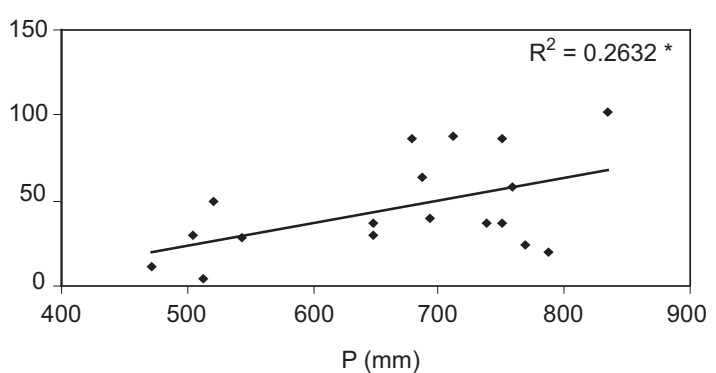

Fig. 5. Correlations between $\mathrm{N}$ balance and $\mathrm{N}$ leaching (on the left), and precipitation and $\mathrm{N}$ leaching (on the right) on the conventional cereal production farm and the pig husbandry farm (* significance at 0.05 level).

\section{Scenarios of $\mathbf{N}$ fertilization levels}

When increasing the $\mathrm{N}$ fertilization level by $20 \%$ on the conventional cereal farm the average $\mathrm{N}$ balance increased by $37 \%$ from $35 \mathrm{~kg} \mathrm{~N}$ ha $^{-1} \mathrm{yr}^{-1}$ to 49

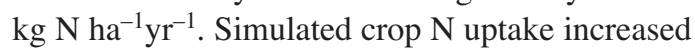
by $8 \%$ from $76 \mathrm{~kg} \mathrm{~N} \mathrm{ha}^{-1} \mathrm{yr}^{-1}$ to $82 \mathrm{~kg} \mathrm{~N} \mathrm{ha}^{-1} \mathrm{yr}^{-1}$ and $\mathrm{N}$ leaching by $43 \%$ from $40 \mathrm{~kg} \mathrm{~N} \mathrm{ha}^{-1} \mathrm{yr}^{-1}$ to $57 \mathrm{~kg} \mathrm{~N} \mathrm{ha}^{-1} \mathrm{yr}^{-1}$. Inorganic $\mathrm{N}$ accumulated in soil during the dry period and leached away during the following rainy seasons. For example on Field 1 the simulated inorganic $\mathrm{N}$ level at the end of the last simulation period (2005) was close to the observed value in year 2000 though inorganic $\mathrm{N}$ level was higher during dry years 2002 and 2003 (Fig. 9). When decreasing the $\mathrm{N}$ fertilization level by $20 \%$ on average, $\mathrm{N}$ balance decreased by $51 \%$ to $17 \mathrm{~kg}$
$\mathrm{N} \mathrm{ha}^{-1} \mathrm{yr}^{-1}$. Crop $\mathrm{N}$ uptake decreased by $8 \%$ to 70 $\mathrm{kg} \mathrm{N} \mathrm{ha}{ }^{-1} \mathrm{yr}^{-1}$ and $\mathrm{N}$ leaching by $13 \%$ to $35 \mathrm{~kg} \mathrm{~N}$ $\mathrm{ha}^{-1} \mathrm{yr}^{-1}$ (Fig 10).

When increasing the $\mathrm{N}$ fertilization level by $20 \%$ on the pig farm the $\mathrm{N}$ balance increased by $30 \%$ from $67 \mathrm{~kg} \mathrm{~N} \mathrm{ha}^{-1} \mathrm{yr}^{-1}$ to $89 \mathrm{~kg} \mathrm{~N} \mathrm{ha}^{-1} \mathrm{a}^{-1}$. Simulated N leaching increased by $26 \%$ from 46 $\mathrm{kg} \mathrm{N} \mathrm{ha}^{-1} \mathrm{yr}^{-1}$ to $58 \mathrm{~kg} \mathrm{Nha}^{-1} \mathrm{yr}^{-1}$ but crop $\mathrm{N}$ uptake did not change. When the $\mathrm{N}$ fertilization level was decreased by $20 \%$, N balance decreased by $35 \%$ to $43 \mathrm{~kg} \mathrm{~N} \mathrm{ha}^{-1} \mathrm{yr}^{-1}$. Crop $\mathrm{N}$ uptake decreased by $6 \%$ to $64 \mathrm{~kg} \mathrm{~N} \mathrm{ha}^{-1} \mathrm{yr}^{-1}$ and $\mathrm{N}$ leaching by $20 \%$ to $37 \mathrm{~kg} \mathrm{~N} \mathrm{ha}^{-1} \mathrm{yr}^{-1}$. According to COUP simulation results, decreasing $\mathrm{N}$ balance by $1 \mathrm{~kg} \mathrm{~N} \mathrm{ha}^{-1} \mathrm{yr}^{-1}$ decreased $\mathrm{N}$ leaching by $0.36 \mathrm{~kg} \mathrm{~N} \mathrm{ha}^{-1} \mathrm{yr}^{-1}$ during period 2000-2005.

When applying manure only in spring on Field 11 the average $\mathrm{N}$ leaching in 2000-2005 decreased 
Rankinen, K. et al. Modelled farm-based nitrogen leaching and nitrogen balance in 2000-2005

Table 6. Monthly precipitation sum at the Jokioinen Observatory for the years 1999-2005.

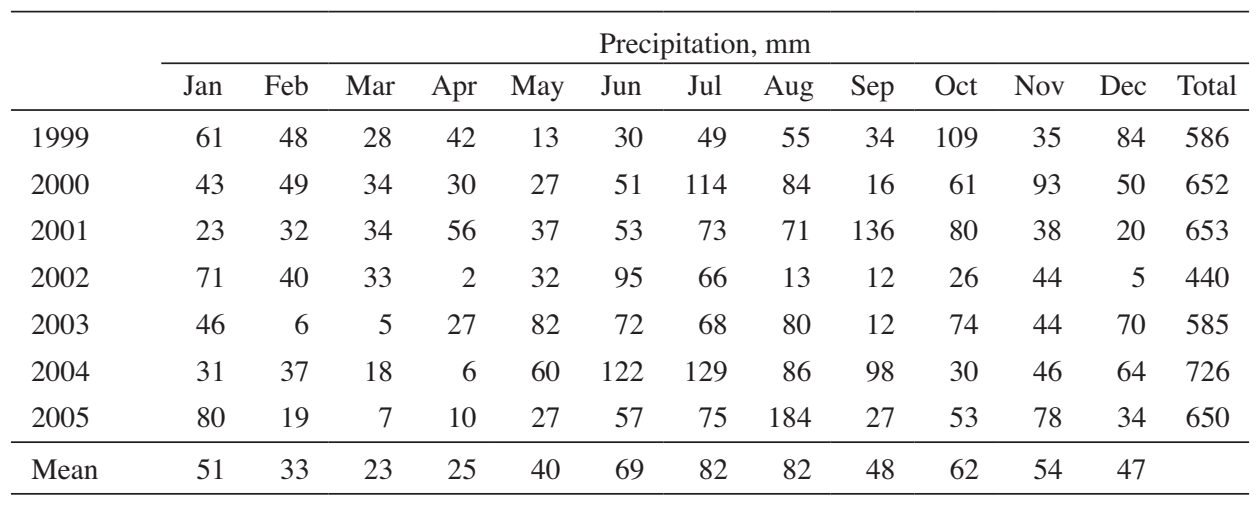

by $7 \%$ from $47 \mathrm{~kg} \mathrm{~N} \mathrm{ha}^{-1} \mathrm{yr}^{-1}$ to $44 \mathrm{~kg} \mathrm{~N} \mathrm{ha}^{-1} \mathrm{yr}^{-1}$. Annual decrease varied between $6 \%$ and $25 \%$. Crop $\mathrm{N}$ uptake slightly increased.

\section{Statistical Analysis of $\mathrm{N}$ balance}

The effect of $\mathrm{N}$ balance on $\mathrm{N}$ leaching was 0.221 ( $\mathrm{N}$ leaching $\mathrm{kg} \mathrm{ha}^{-1} \mathrm{yr}^{-1} / \mathrm{N}$ balance $\mathrm{kg} \mathrm{ha}^{-1} \mathrm{yr}^{-1}$ ) when it was alone in the ANCOVA model with $p=0.001$ (Table 8). Cumulative inclusion of precipitation, $\mathrm{N}$ mineralization rate and either plant $\mathrm{N}$ uptake or $\mathrm{N}$ fertilization had only a small influence on the effect of $\mathrm{N}$ balance on $\mathrm{N}$ leaching, at least when compared to the $256 \%$ increase in the value of the regression coefficient that took place when both $\mathrm{N}$ uptake and $\mathrm{N}$ fertilization were further added into the model (Table 8). These two covariates were added simultaneously, because there was a statistically significant positive correlation (Kendall's Tau b) between them (Table 9).

\section{Discussion}

In this study the main aim was to simulate the fate of inorganic $\mathrm{N}$ added to soil in fertilizers and manure based on a relatively simple monitoring program. Nutrient balances are commonly used methods to summarize information of nutrient inputs and outputs to the system, but in general they contain a large amount of uncertainty. Ap-

Table 7. Monthly mean air temperature at the Jokioinen Observatory for the years 1999-2005.

\begin{tabular}{|c|c|c|c|c|c|c|c|c|c|c|c|c|c|}
\hline & \multirow[b]{2}{*}{ Jan } & \multirow[b]{2}{*}{ Feb } & \multirow[b]{2}{*}{ Mar } & \multirow[b]{2}{*}{ Apr } & \multirow[b]{2}{*}{ May } & \multicolumn{3}{|c|}{ Temperature, ${ }^{\circ} \mathrm{C}$} & \multirow[b]{2}{*}{ Sep } & \multirow[b]{2}{*}{ Oct } & \multirow[b]{2}{*}{ Nov } & \multirow[b]{2}{*}{ Dec } & \multirow[b]{2}{*}{ Mean } \\
\hline & & & & & & Jun & Jul & Aug & & & & & \\
\hline 1999 & -6.3 & -7.7 & -1.8 & 5.0 & 7.5 & 17.4 & 17.5 & 14.1 & 11.6 & 5.8 & 1.5 & -3.7 & 5.1 \\
\hline 2000 & -3.5 & -2.8 & -1.9 & 5.7 & 10.3 & 13.5 & 15.6 & 14.1 & 8.5 & 8.1 & 3.9 & 0.7 & 6.1 \\
\hline 2001 & -2.3 & -8.4 & -4.3 & 5.1 & 8.7 & 13.6 & 18.9 & 15.3 & 11.2 & 7.3 & -0.7 & -8.1 & 4.8 \\
\hline 2002 & -4.5 & -1.7 & -0.6 & 5.2 & 11.3 & 15.4 & 18.2 & 17.9 & 10.1 & -0.4 & -3.9 & -9.0 & 4.9 \\
\hline 2003 & -10.5 & -6.9 & -1.2 & 2.2 & 9.7 & 12.9 & 19.7 & 15.0 & 10.7 & 2.7 & 2.1 & -1.7 & 4.6 \\
\hline 2004 & -7.5 & -4.9 & -1.8 & 4.9 & 9.6 & 12.2 & 15.5 & 15.7 & 11.5 & 4.8 & -0.7 & -0.8 & 4.9 \\
\hline 2005 & -1.8 & -5.5 & -6.6 & 4.3 & 9.6 & 13.4 & 18.0 & 15.3 & 11.5 & 6.7 & 3.0 & -5.1 & 5.3 \\
\hline Mean & -5.2 & -5.4 & -2.6 & 4.6 & 9.5 & 14.1 & 17.6 & 15.3 & 10.7 & 5.0 & 0.7 & -3.9 & 5.1 \\
\hline
\end{tabular}




\section{Field 5}

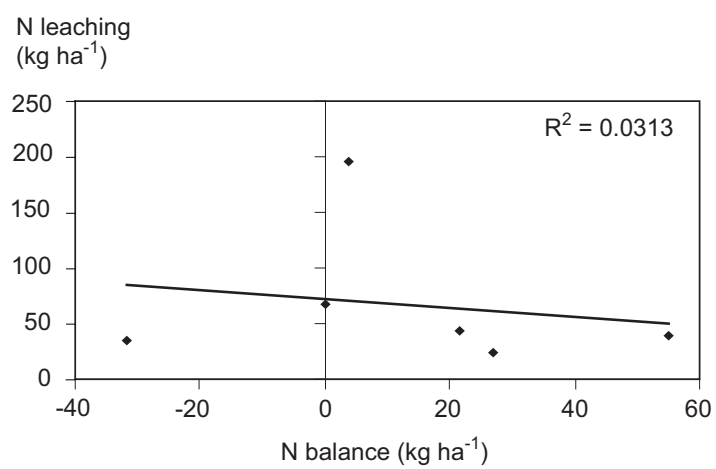

Field 9

$\mathrm{N}$ leaching

$\left(\mathrm{kg} \mathrm{ha}^{-1}\right)$

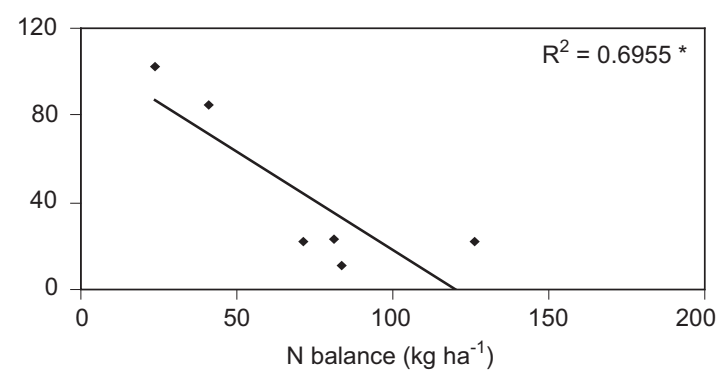

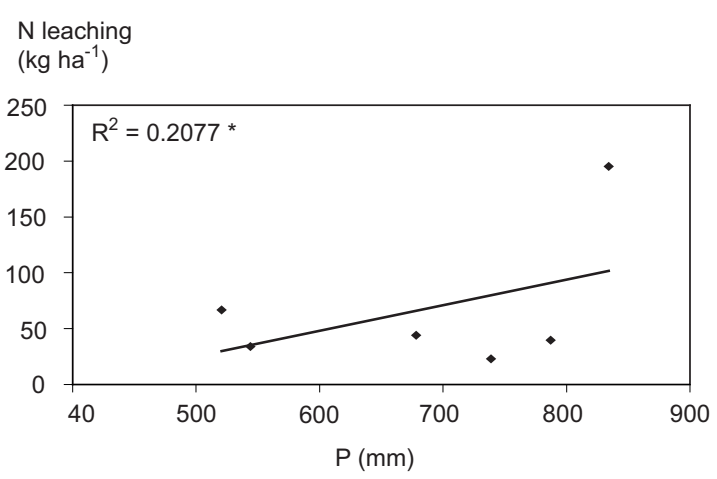

$\mathrm{N}$ leaching

$\left(\mathrm{kg} \mathrm{ha}^{-1}\right)$

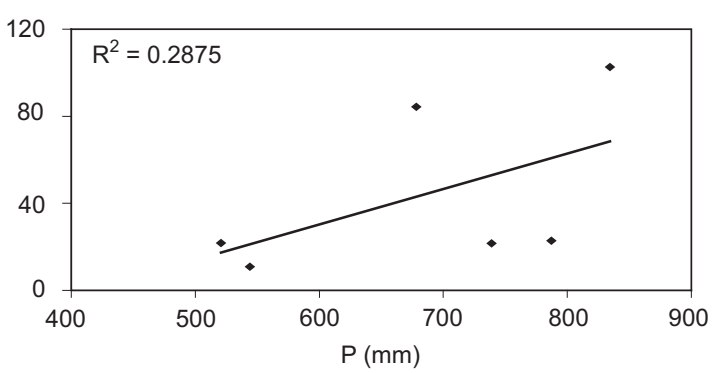

Fig. 6. Correlations between $\mathrm{N}$ balance and $\mathrm{N}$ leaching (on the left) and precipitation and $\mathrm{N}$ leaching (on the right) on Field 5 and Field 9 (* significance at 0.05 level).

proximate values for the relative errors of $\mathrm{N}$ flows on farms in the Netherlands were highest in inputs of manure (10-20\%) and plant material (5-20\%) and outputs of leaching (50-200\%) and volatilization (50-200\%). The error of crop output was estimated to be 5-10\%. Total input errors were estimated to be $5-15 \%$ and output errors $10-20 \%$ (FAO 2003).

Oenema et al. (2003) classified uncertainties into biases which are defined as systematic devia-

\section{Mineralization $\mathrm{N}$ rate}

$\left(\mathrm{g} \mathrm{m}^{-2}\right.$ day $\left.^{-1}\right)$

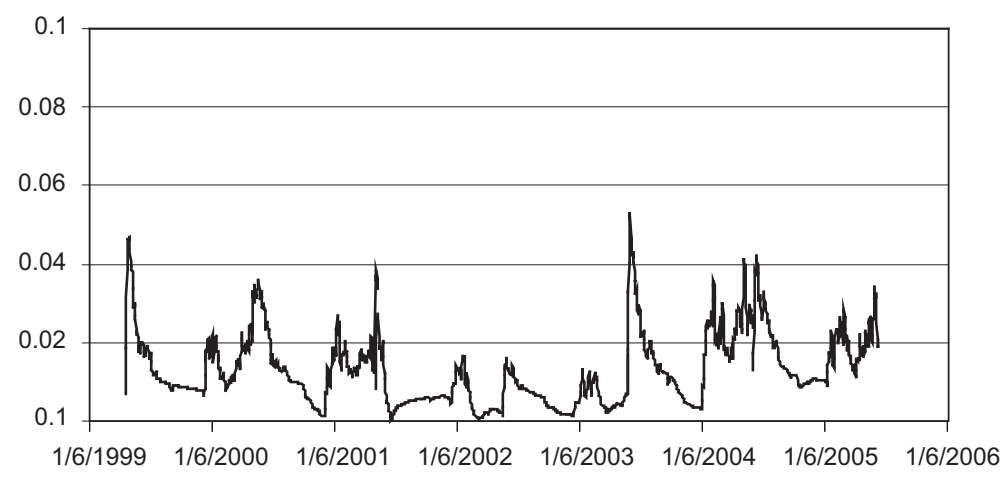

Fig. 7. Simulated mineralization rate in Field 1. 
a)

N leaching
$\left(\mathrm{kg} \mathrm{ha}^{-1}\right)$

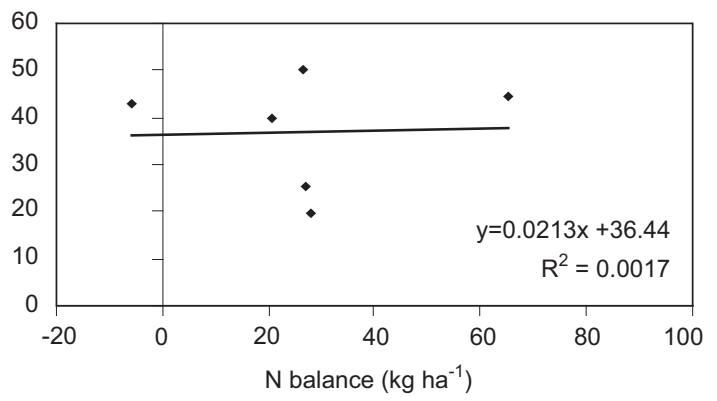

b)

\author{
$\mathrm{N}$ leaching \\ $\left(\mathrm{kg} \mathrm{ha}^{-1}\right)$
}

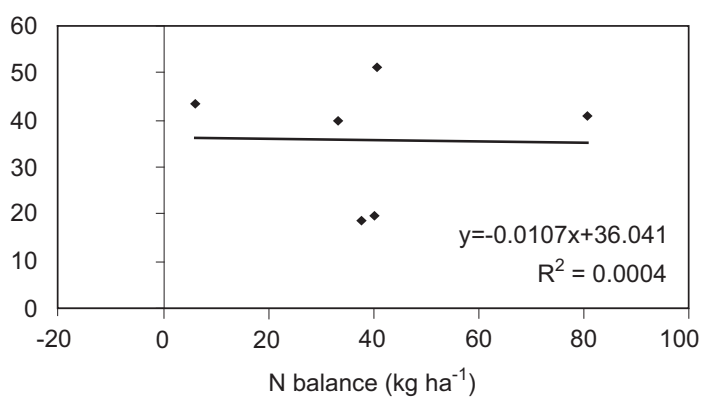

Fig. 8. Effect of crop uptake scenario on the relationship between $\mathrm{N}$ balance and $\mathrm{N}$ leaching on Field 1. a) base scenario b) crop uptake $-20 \%$.

tion and errors defined as random variation. Data manipulation biases are due to generalization, averaging and upscaling, which may lead to loss of information. Personal biases depend on the method of conceptual simplification of an agroecosystem. There may also be a bias caused by stakeholders attempting to manipulate $\mathrm{N}$ balance.

Oenema et al. (2003) mentioned 'within-plot' heterogeneity as an example of sampling error. In the present study there were discontinuations in calibration on fields fertilized by manure. Although composite samples were collected in order to obtain a representative set of samples (sampling biases), it was possible that manure was not evenly distributed in soil on large fields, leading to too high or low measured values. Measurement biases caused by laboratory practices may cause a coefficient of variation of up to $10 \%$ in wellhomogenized soil samples (Oenema et al. 2003), which was represented by the interval of variation in calibration of the COUP model.

Conceptualization of the system probably caused the largest proportion of uncertainties in this study. Standard growth curves of crops were used, which might have lead to overestimation of $\mathrm{N}$ uptake in some cases. On the other hand, the results of scenario runs indicated that uncertainties in crop $\mathrm{N}$ uptake were not reflected in simulated $\mathrm{N}$ leaching because the COUP model was calibrated against measured inorganic $\mathrm{N}$ content in soil.
Fig. 9. Simulated inorganic N content in a $0-80 \mathrm{~cm}$ soil profile in Field 1 of the crop production farm when applying $+/-20 \% \mathrm{~N}$ fertilizer.

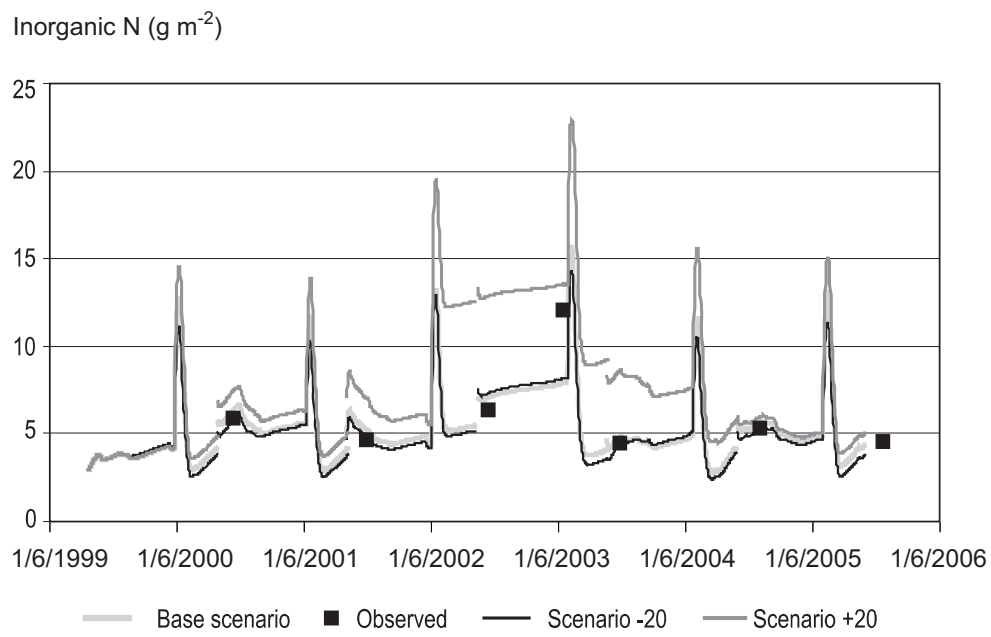




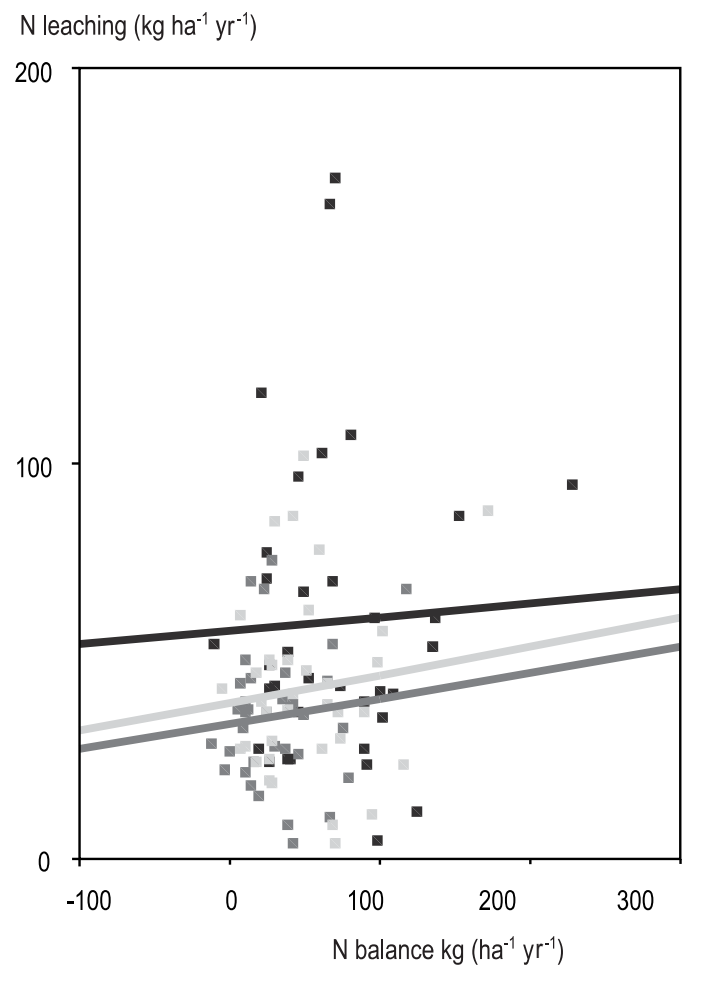

Fertilization level

- Increase by $20 \%$ Decrease by $20 \%$ Present level

Fig. 10. Relationship between $\mathrm{N}$ balance and $\mathrm{N}$ leaching according to different scenarios.

When crop $\mathrm{N}$ uptake was lower than in the base scenario, fertilizer $\mathrm{N}$ was accumulated in soil after the growing season. This accumulated $\mathrm{N}$ was compensated by a lower mineralization rate from the soil organic $\mathrm{N}$ pool so that the observed inorganic
$\mathrm{N}$ content in soil was reached in the calibration process. In the base scenario $\mathrm{N}$ balances varied between $62 \mathrm{~kg} \mathrm{~N} \mathrm{ha}^{-1} \mathrm{yr}^{-1}$ on the fields of the pig farm and $27 \mathrm{~kg} \mathrm{~N} \mathrm{ha}^{-1} \mathrm{yr}^{-1}$ in organic production. The regional $\mathrm{N}$ balance of $50 \mathrm{~kg} \mathrm{~N} \mathrm{ha} \mathrm{yr}^{-1}$ (Ministry of Agriculture and Forestry 2004b) in southwestern Finland falls within this range. Further, ammonia volatilization was not included in the $\mathrm{N}$ balance calculations. In all cases farmers ploughed manure into soil after application and therefore volatilization losses can be assumed to be small. Thus, uncertainty would have been reduced if crop samples had been taken from fields to calculate crop uptake of $\mathrm{N}$ or if manure analysis had been used in calculating the $\mathrm{N}$ content of manure.

Simulated N leaching from fields of different production systems was in the range reported in the literature when the scale difference is taken into consideration. In this COUP model application $\mathrm{N}$ leaching was simulated from the uppermost $80 \mathrm{~cm}$ soil layer in a soil profile, but most of the field measurements were made in field or research catchment scale. In six years long experiment Deelstra et al. (2004) observed that average N losses measured in field scale were $73 \%$ and those measured in catchment scale were $37 \%$ of losses measured in plot scale. For example Niinioja (1993) reported that in several empirical studies in Nordic countries, $\mathrm{N}$ leaching from fields fertilized by manure varied between 1 and $58 \mathrm{~kg} \mathrm{~N}$ $\mathrm{ha}^{-1} \mathrm{yr}^{-1}$. Turtola and Kemppainen (1998) reported that annual $\mathrm{N}$ losses in surface runoff and drainage water varied between $5-40 \mathrm{~kg} \mathrm{~N}$ ha $^{-1}$ from grass fields fertilized by slurry. Jaakkola (1984) reported $\mathrm{N}$ leaching of $1-38 \mathrm{~kg} \mathrm{~N}^{-1} \mathrm{yr}^{-1}$ from

Table 8. The effect of $\mathrm{N}$ balance on $\mathrm{N}$ leaching as such and adjusted for precipitation (Prec), $\mathrm{N}$ mineralization (Nmin), $\mathrm{N}$ fertilization (Nfert) and $\mathrm{N}$ uptake (Nupt) in the ANCOVA model.

\begin{tabular}{llcc}
\hline Covariates in addition to N balance & $\begin{array}{l}\text { Coefficient, } \\
\mathrm{kg} \mathrm{N} \mathrm{ha}^{-1} / \mathrm{kg} \mathrm{N} \mathrm{ha}^{-1}\end{array}$ & $\begin{array}{l}\text { Significance, } \\
\text {-value }\end{array}$ & $\begin{array}{l}\text { Significance of } \\
\text { added covariates }\end{array}$ \\
\hline none & 0.22 & 0.009 & - \\
+ Prec & 0.25 & 0.001 & 0.000 \\
+ Prec + Nmin & 0.32 & 0.000 & 0.006 \\
+ Prec + Nmin + Nfert / + Nupt & $0.32 / 0.28$ & $0.087 / 0.000$ & $0.988 / 0.011$ \\
+ Prec + Nmin + Nfert and Nupt & 0.79 & 0.023 & 0.105 \\
\hline
\end{tabular}


Rankinen, K. et al. Modelled farm-based nitrogen leaching and nitrogen balance in 2000-2005

Table 9. Correlations between covariates of ANCOVA analysis.

\begin{tabular}{lcccccc}
\hline & N balance & N leaching & N uptake & Precipitation & $\begin{array}{l}\text { N mineralization } \\
\text { rate }\end{array}$ & N fertilization \\
\hline N balance & 1.000 & 0.088 & 0.050 & -0.097 & $-0.285^{* *}$ & $0.715^{* * *}$ \\
N leaching & 0.088 & 1.000 & 0.110 & $0.328^{* *}$ & 0.041 & 0.091 \\
N uptake & 0.050 & 0.110 & 1.000 & 0.062 & 0.007 & $0.304 * *$ \\
Precipitation & -0.097 & $0.328^{* *}$ & 0.062 & 1.000 & 0.036 & -0.042 \\
N mineralization rate & $-0.285^{* *}$ & 0.041 & 0.007 & 0.036 & 1.000 & $-0.282^{* *}$ \\
N fertilization & $0.715^{* *}$ & 0.091 & $0.304 * *$ & -0.042 & $-0.282^{* *}$ & 1.000 \\
\hline
\end{tabular}

** Significant at the $p<0.01$ level

clay soil fields under grass or cereal production and Vuorenmaa et al. (2002) 13.8-16.2 kg N $\mathrm{ha}^{-1} \mathrm{yr}^{-1}$ as specific loss from the arable land part of agricultural research catchments. Simulated $\mathrm{N}$ leaching in the present study was well in accordance with these measured values with high annual variation.

A large proportion of simulated $\mathrm{N}$ leaching occurred outside the growing season. This was partly due to high simulated mineralization rate in soil in early autumn. Precipitation at this time was not considerably higher than in the other seasons but on the other hand evapotranspiration was low, leading to high runoff. In other Finnish studies losses of $\mathrm{N}$ have been observed to be high in autumn after harvest (Kallio et al. 1997). Wivstad et al. (2005) reported mineralization of soil organic matter in agricultural soils outside the growing season which may continue under the snow-pack throughout the winter (Schmidt et al. 1999, Stottlemyer and Toczydlowski 1999, Schimel et al. 2004). According to Turtola and Kemppainen (1998) and Turtola et al. 2007 the general pattern for water flow in ploughed soil was dominated by drainage flow in autumn.

The average simulated $\mathrm{N}$ mineralization in soil (between $40 \mathrm{~kg} \mathrm{~N} \mathrm{ha}^{-1} \mathrm{yr}^{-1}$ on the pig farm and 55 $\mathrm{kg} \mathrm{N} \mathrm{ha}^{-1} \mathrm{yr}^{-1}$ on the organic farm) was at a plausible level (Sippola and Yläranta 1985, Sippola 2000, Rankinen et al. 2006) although somewhat lower than that estimated by Paustian et al. (1990) in Sweden (80-92 $\mathrm{kg} \mathrm{N} \mathrm{ha}^{-1} \mathrm{yr}^{-1}$ in barley). There was negative correlation between $\mathrm{N}$ fertilization and simulated $\mathrm{N}$ mineralization, which may be simply due to the fact that $\mathrm{N}$ fertilization was low and the mineralization rate high on the organic farm. On the other hand $\mathrm{N}$ fertilizations tended to be high on farms practising animal husbandry, but mineralization rates were there at the same level as for cereal production.

There were differences in simulated $\mathrm{N}$ leaching from different fields depending on production type. In the fields of the pig farm leaching was highest, partly because manure was applied in autumn when dissolved $\mathrm{N}$ was easily washed away. In scenario simulations $\mathrm{N}$ leaching could be reduced either by decreasing the $\mathrm{N}$ balance or by applying manure only in spring. Both Niinioja (1993) and Turtola and Kemppainen (1998) observed higher leaching of $\mathrm{N}$ when slurry was applied on fields in autumn rather than in spring. Kyllmar et al. (2006) studied nutrient leaching from small agricultural catchments in Sweden and observed connection between decreasing nitrate trends and smaller amounts of applied manure, especially in autumn, and decrease in the area of spring cereals.

Low crop $\mathrm{N}$ uptake in the organic farm led to relatively high $\mathrm{N}$ balances and simulated $\mathrm{N}$ leaching, although the $\mathrm{N}$ application rate in manure was low. Highest simulated annual leaching occurred from a field where inorganic $\mathrm{N}$ had accumulated in soil after green fallow during a dry growing season. Accumulated $\mathrm{N}$ was washed away during the following autumn/winter but also during the following growing season, when crop uptake was relatively 
low. Studies of nutrient leaching from fields under organic farming give contradictory results. During a relatively shoft time period, Syväsalo et al. (2006) could not confirm the environmental advantages of organic farming when studying $\mathrm{N}$ leaching and greenhouse gas emissions in Finland. On the other hand in a systems modelling study in Denmark Hansen et al. (2000) concluded that N leaching was lower from organic systems than from conventional farming due to lower total input of $\mathrm{N}$ and extensive use of catch crops.

On an annual basis $\mathrm{N}$ balance and $\mathrm{N}$ leaching on farms representing different production lines were not related. This result was in agreement with Ulén et al. (2005) who did not find any relationship between $\mathrm{N}$ balances and actual leaching losses. On the other hand, both Korsaeth et al. (2002) and Salo and Turtola (2006) found that a linear regression model explained $\mathrm{N}$ leaching better when precipitation was also added as a predictor together with $\mathrm{N}$ balance, although the average $\mathrm{N}$ balance calculated for several years proved to be the best predictor of $\mathrm{N}$ leaching.

In the present study the statistical evaluation indicated significant positive correlation between $\mathrm{N}$ balance and simulated $\mathrm{N}$ leaching, especially when supported by constant values of precipitation and $\mathrm{N}$ mineralization rate. $\mathrm{N}$ balance had statistically significant negative correlation with simulated $\mathrm{N}$ mineralization rate and statistically significant positive correlation with $\mathrm{N}$ fertilization; $\mathrm{N}$ leaching was correlated only with precipitation. When both $\mathrm{N}$ fertilization level and plant $\mathrm{N}$ uptake were included in statistical evaluation as constants, the effect of $\mathrm{N}$ balance on simulated $\mathrm{N}$ leaching increased considerably, although separately they did not have any effect. The latter model was to some extent an artificial scenario, as $\mathrm{N}$ fertilization is the main input and crop $\mathrm{N}$ uptake the main output when calculating $\mathrm{N}$ balances. Crop $\mathrm{N}$ uptake and $\mathrm{N}$ fertilization level were positively correlated, but changing the fertilization level increased or decreased plant $\mathrm{N}$ uptake only slightly. Although crop N uptake was correlated with $\mathrm{N}$ fertilization level, it did not correlate with $\mathrm{N}$ balance. The results of the statistical analyses suggest that $\mathrm{N}$ balance may be used as an indicator of $\mathrm{N}$ leaching when longer time-period is considered to equalize the strong effects of annual precipitation and cultivation practices.

According to COUP model simulations in the years 2000-2006, decreasing $\mathrm{N}$ balance by $1 \mathrm{~kg} \mathrm{~N}$ $\mathrm{ha}^{-1} \mathrm{yr}^{-1}$ decreased simulated $\mathrm{N}$ leaching by 0.32 $\mathrm{kg} \mathrm{N} \mathrm{ha}^{-1} \mathrm{yr}^{-1}$ when external factors (precipitation and $\mathrm{N}$ mineralization rate) were kept constant. Oenema et al. (2005) observed in the Netherlands that measured leaching to surface waters was decreased by $0.12 \mathrm{~kg} \mathrm{~N} \mathrm{ha}^{-1} \mathrm{yr}^{-1}$ when $\mathrm{N}$ balance decreased by $1 \mathrm{~kg} \mathrm{~N} \mathrm{ha}^{-1} \mathrm{yr}^{-1}$. Furthermore, an increase in $\mathrm{N}$ balance of $10 \mathrm{~kg} \mathrm{~N} \mathrm{ha}^{-1} \mathrm{yr}^{-1}$ implied an increase in measured $\mathrm{N}$ runoff of $1.5 \mathrm{~kg} \mathrm{~N} \mathrm{ha}^{-1} \mathrm{yr}^{-1}$ in southern Norway (Korsaet and Eltun 2000) and 1.5-5.7 $\mathrm{kg} \mathrm{N} \mathrm{ha}^{-1} \mathrm{yr}^{-1}$ in Finland (Salo and Turtola 2006). These relationships are probably dependent on the actual $\mathrm{N}$ balance level, because decreasing the $\mathrm{N}$ balance to zero would not decrease $\mathrm{N}$ leaching correspondingly to zero.

Kirchmann et al. (2002) recommended reducing $\mathrm{N}$ inputs to soil to levels slightly below those expected to give the optimum yield if the target is to reduce $\mathrm{N}$ leaching. In the present study, when increasing $\mathrm{N}$ fertilization, higher $\mathrm{N}$ input was reflected in slightly higher crop uptake but also in higher annual $\mathrm{N}$ leaching and accumulation in soil. Accumulated $\mathrm{N}$ was easily leached from soils during rainy seasons, leading to high variation in annual N leaching. Salo and Turtola (2006) concluded that average $\mathrm{N}$ balances were useful indicators for $\mathrm{N}$ leaching when cultivation techniques included environmentally risky management, but when good agricultural practice was maintained, $\mathrm{N}$ leaching was not predicted by $\mathrm{N}$ balances.

\section{Conclusions}

According to the COUP modelling results $\mathrm{N}$ balance and inorganic $\mathrm{N}$ leaching from fields did not clearly correlate on an annual basis. One reason for this was that inorganic $\mathrm{N}$ tended to accumulate in soil during dry periods. During rainy seasons it was easily washed away. Thus annual hydrology 


\section{AGRICULTURAL AND FOOD SCIENCE}

Rankinen, K. et al. Modelled farm-based nitrogen leaching and nitrogen balance in 2000-2005

affected $\mathrm{N}$ leaching very strongly. Further, N leaching outside the growing season was high, which was explained by precipitation but also by high $\mathrm{N}$ mineralization in soil.

Simulated N leaching was lowest from fields of conventional cereal production with low $\mathrm{N}$ balances. When decreasing fertilizer $\mathrm{N}$ input, the mean $\mathrm{N}$ balance decreased, which was reflected in lower leaching losses but also in lower crop uptake of N. Nitrogen leaching from pig and cattle production farms may be reduced by decreasing the $\mathrm{N}$ balance but also by changing manure application from autumn to spring, which did not influence crop uptake of N. Other potential causes of high leaching were high $\mathrm{N}$ balances due to low crop uptake or high input of $\mathrm{N}$ (high fertilization or increased mineralization of $\mathrm{N}$ in soil).

Nitrogen balance may be a relatively usable indicator of $\mathrm{N}$ leaching over longer time periods when the strong influence of precipitation and cultivation practices is equalized. High positive $\mathrm{N}$ balances are associated with high accumulation of $\mathrm{N}$ in soil and further high risk of $\mathrm{N}$ leaching during rainy seasons.

\section{Acknowledgements}

This work was funded by the Finnish Ministry of Agriculture and Forestry. The authors thank the farmers who kindly permitted access to their fields and crop management data for this study and Leena Mäkäräinen, Leena Seppänen and Matti Ylösmäki for their assistance in the field surveys.

\section{References}

Apetroaie-Constantin, C., Shaheen, R., Andrup, L., Smidt, L., Rita, H. \& Salkinoja-Salonen M. 2007. Environment driven cereulide production by emetic strains of Bacillus cereus; Submitted to International Journal of Food Microbiology.

Arheimer, B. \& Brandt, M. 2000. Watershed modelling of non-point nitrogen losses from arable land to the Swedish coast in 1985 and 1994. Journal of Ecological Engineering 14: 389-404.

Babbie E. 1975. The Practice of Social Research. 10th ed. Wadsworth: Thomson Learning Inc. ISBN 0-534-62029-9

Deelstra, J., Abramenko, K., Vagstad, N., Jansons, V., Sudars, R. \& Dzalbe, I. 2004. Hydrological pathways, scale issues and nitrogen runoff: a case study in Latvian catchment. In: Järvet, A. (Ed.) XXIII Nordic Hydrological Conference, Tallinn, Estonia 8-12 August 2004, Selected articles. NHP Report No. 48. pp. 219-229.
European Environment Agency 2005. Agriculture and environment in EU-15 - the IRENA indicator report. EEA Report No 6/2005. $128 \mathrm{p}$.

FAO. 2003. Assessment of soil nutrient balance. Fertilizer and plant nutrition bulletin 14. $87 \mathrm{p}$.

Granlund, K., Rekolainen, S., Grönroos, J., Nikander, A. \& Laine, Y. 2000. Estimation of the impact of fertilisation rate on nitrate leaching in Finland using a mathematical simulation model. Agriculture, Ecosystems \& Environment 80: 1-13.

Hansen, B., Kristensen, E. S., Grant, R., Hogh-Jensen, H., Simmelsgaard, S. E. \& Olesen, J. E. 2000. Nitrogen leaching from conventional versus organic farming systems - a systems modelling approach. European Journal of Agronomy 13: $65-82$.

Information center of agriculture and forestry. 2004. Yearbook of farm statistics. $268 \mathrm{p}$.

Jaakkola, A. 1984. Leaching losses of nitrogen from a clay soil under grass and cereal crops in Finland. Plant and Soil 76: 59-66.

Jansson, P.-E. \& Karlberg, L. 2001. Coupled heat and mass transfer model for soil-plant-atmosphere systems. TRITAAMI REPORT 30 87, Division of Land and Water Resources, Department of Civil and Environmental Engineering, Royal Institute of Technology. $321 \mathrm{p}$.

Kallio, K., Rekolainen, S., Ekholm, P., Granlund, K., Laine, Y., Johnsson, H., \& Hoffman, M. 1997. Impact of climatic change on agricultural nutrient losses in Finland. Boreal Environment Research 2: 33-52.

Kirchmann, H., Johnston, A.E.J. \& Bergström, L. 2002. Possibilities for reducing nitrate leaching from agricultural land. Ambio 31: 404-408.

Korsaeth, A. \& Eltun, R. 2000. Nitrogen mass balances in conventional, integrated and ecological cropping systems and the relationship between balance calculations and nitrogen runoff in an 8-year field experiment in Norway. Agriculture Ecosystems \& Environment 79: 199-214.

Kyllmar, K. 2004. Nitrogen leaching in small agricultural catchments. Modelling and monitoring for assessing state, trends and effects of counter measures. Department of soil sciences. Uppsala, Swedish University of Agricultural Sciences. Agraria 485. 37 p.

Kyllmar, K., C Carlsson, C., Gustafson, A., Ulén, B. \& Johnsson, H. 2006. Nutrient discharge from small agricultural catchments in Sweden Characterization and trends. Agriculture Ecosystems \& Environment 115: 15-26.

Lord, E. I., Anthony, S.G. \& Goodlass, G. 2002. Agricultural nitrogen balance and water quality in the UK. Soil Use and Management 18: 363-369.

Mattila, P. 2007. Spring barley yeald and nitrogen recovery after application of peat manure and pig slurry. Agricultural and Food Science 15: 124-137.

Mattila, P., Grönroos, J., Rankinen, K., Laitinen, P., Karhu, E. \& Granlund, K. 2008. Ympäristötuen mukaiset viljelytoimenpiteet ja niiden vaikutukset vesistökuormitukseen vuosina 2003-2005. Suomen ympäristö. In press.

Ministry of Agriculture and Forestry 2004a. Agricultural Support. http://www.mmm.fi/en/index/frontpage/agriculture/support. html. Cited 7 November 2007.

Ministry of Agriculture and Forestry 2004b. Mid-term evaluation of the Horizontal Rural Development Programme. Publications of the Ministry of Agriculture and Forestry 1/2004. In Finnish with English summary. Helsinki. 272 p.

Mitikka, S., Britschgi, R., Granlund, K., Grönroos, J., Kauppila, P., Mäkinen, R., Niemi, J., Pyykkönen, S., Raateland, A. \& Silvo, K. 2005. Report on the implementation of the Nitrates Directive in Finland 2004. The Finnish Environment 741. $92 \mathrm{p}$.

Niinioja, R. 1993. Lietelannan levitys ja ravinteiden huuhtoutuminen. Vesi- ja ympäristöhallinnon julkaisuja - sarja A 150. $90 \mathrm{p}$. 


\section{AGRICULTURAL AND FOOD SCIENCE}

Vol. 16 (2007): 387-406

OECD/EUROSTAT 2003. Gross Nitrogen Balances. Handbook. December 2003. http//:webdomino1.oecd.org/comnet/agr/ aeiquest.nsf. Cited 7 November 2007.

Oenema, O., Kros, H. \& de Vries, W. 2003. Approaches and uncertainties in nutrient budgets: implications for nutrient management and environmental policies. European Journal of Agronomy 20: 3-16

Oenema, O., van Liere, L. \& Schoumans, O. 2005. Effects of lowering nitrogen and phosphorus surpluses in agriculture on the quality of groundwater and surface waters in the Netherlands. Journal of Hydrology 304: 289-301.

Palva, R., Rankinen, K., Granlund, K., Grönroos, J., Nikander, A. \& Rekolainen, S. 2001. Maatalouden ympäristötuen toimenpiteiden toteutuminen ja vaikutukset vesistökuormitukseen vuosina 1995-1999. MYTVAS-projektin loppuraportti. Suomen ympäristö, Ympäristönsuojelu 478. 92 p.

Paustian, K., Bergström, L., Jansson, P.E. \& Johnsson, H.: 1990. Ecosystem dynamics. Ecological Bulletins 40: 153-180.

Pietiläinen, O.-P. \& Räike, A. 1999. Typpi ja fosfori Suomen sisävesien minimiravinteena. Suomen ympäristö 313. 64. p.

Pyykkönen, S., Grönroos, J., Rankinen, K., Laitinen, P., Karhu, E. \& Granlund, K. 2004. Ympäristötuen mukaiset viljelytoimenpiteet ja niiden vaikutukset vesistökuormitukseen vuosina 2000-2002. Suomen ympäristö 711. 119 p.

Rankinen, K., Granlund, K., Palojärvi, A., Pietola, L., Regina, K. \& Uusi-Kämppä, J. 2006. Hydrologisten ja typen prosessien mallinnus Lintupajun suojakaistakoekentällä. In: Virkajärvi, P. \& Uusi-Kämppä, J. (Eds). Laitumien ja suojavyöhykkeiden ravinnekierto ja ympäristökuormitus. Maa- ja elintarviketalous 76. p 138-148.

Salo, T. \& Turtola, E. 2006. Nitrogen balance as an indicator of nitrogen leaching in Finland. Agriculture Ecosystems \& Environment 113: 98-107.

Salo, T., Lemola, R. \& Esala, M. 2007. National and regional net nitrogen balances in Finland in 1990-2005. Agricultural and Food Science in Finland 16: 366-375.

Schimel, J. P., Bilbrough, C. \& Welker, J.M. 2004. Increased snow depth affects microbial activity and nitrogen mineralization in two Arctic tundra communities. Soil Biology \& Biochemistry 36: 217-227.

Schmidt, I. K., Jonasson, S.\& Michelsen, A. 1999. Mineralization and microbial immobilization of $\mathrm{N}$ and $\mathrm{P}$ in arctic soils in relation to season, temperature and nutrient amendment. Applied Soil Ecology 11: 147-160.

Sippola, J. 2000. Estimation of soil nitrate in the spring as a basis for adjustment of nitrogen fertiliser rates. Agricultural and Food Science in Finland 9: 71-77.
Sippola, J. \& Yläranta, T. 1985. Mineral nitrogen reserves in soil and nitrogen fertilization of barley. Annales Agriculturae Fenniae 24: 117-124.

Stottlemyer, R. \& Toczydlowski D. 1999. Nitrogen mineralization in a mature boreal forest, Isle Royale, Michigan. Journal of Environmental Quality 28: 709-720.

Syväsalo, E., Regina, K., Turtola, E., Lemola, R. \& Esala, M. 2006. Fluxes of nitrous oxide and methane, and nitrogen leaching from organically and concentionally cultivated soil in western Finland. Agriculture Ecosystems \& Environment 113: 342-348.

Tamminen, T. \& Andersen, T. 2007. Seasonal phytoplankton nutrient limitation patterns as revealed by bioassays over Baltic Sea gradients of salinity and eutrophication. Marine Ecology Progress Series 340, 121-138.

Turtola, E. \& Kemppainen E. 1998. Nitrogen and phosphorus losses in surface runoff and drainage water after application of slurry and mineral fertilizer to perennial grass ley. Agricultural and Food Science in Finland 7: 569-581.

Turtola, E., Alakukku, L., Uusitalo, R \& Kaseva, A. 2007. Surface runoff, subsurface drainflow and soil erosion as affected by tillage in a clayey Finnish soil. Agricultural and Food Science in Finland: 16: 332-351.

Ulén, B., Aronsson, H., Torstensson, G. \& Mattson, L. 2005. Phosphorus and nitrogen turnover and risk of waterborne phosphorus emissions in crop rotations on a clay soil in southwest Sweden. Soil Use and Management 21: 221-230.

Valpasvuo-Jaatinen, P., Rekolainen, S. \& Latostenmaa, H. 1997. Finnish agriculture and its sustainability: Environmental impacts. Ambio 26: 448-455.

Viljavuuspalvelu 2000. Viljavuustutkimuksen tulkinta peltoviljelyssä. Viljavuuspalvelu Oy. Mikkeli. $31 \mathrm{p}$.

Virtanen, H. \& Nousiainen, J. 2005. Nitrogen and phosphorus balances on Finnish dairy farms. Agricultural and Food Science 14: 166-180.

Vitousek, P. M., Aber, J.D., Howarth, R.W., Likens, G.E., Matson, P.A., Schindler, D.W., Schlesinger, W.H. \& Tilman, D.G. 1997. Human alteration of the global nitrogen cycle: sources and consequences. Ecological Applications 7: 737-750.

Vuorenmaa, J., Rekolainen, S., Lepistö, A., Kenttämies, K. \& Kauppila, P. 2002. Losses of nitrogen and phosphorus from agricultural and forest areas in Finland during the 1980s and 1990s. Environmental Monitoring and Assessment 76: 213-248.

Wivstad, M., Dahlin, A. S. \& Grant, C. 2005. Perspectives on nutrient management in arable farming systems. Soil Use and Management 21: 113-121. 


\title{
SELOSTUS
}

\section{Simuloidun typen huuhtouman ja peltotaseen suhde neljällä lounaissuomalaisella maatilalla vuosina $2000-2005$}

\author{
Katri Rankinen, Tapio Salo, Kirsti Granlund ja Hannu Rita \\ Suomen ympäristökeskus, MTT ja Helsingin yliopisto
}

Typpitase kuuluu niihin EU:n ympäristöindikaattoreihin, joiden avulla yritetään seurata maataloudessa tapahtuvia muutoksia. Typpitaseessa lasketaan maahan jääneen typen ylijäämä, kun lannoitteissa lisätyn typen määrästä vähennetään poistumat, kuten sadon typenotto. Tässä tutkimuksessa arvioitiin typpitaseen käyttökelpoisuutta mineraalitypen huuhtoutumisen arvioinnissa lounaissuomalaisilta pelloilta. Matemaattisen, prosessipohjaisen COUP-mallin (Coupled heat and mass transfer model for soil-plant-atmosphere system, entinen SOIL/ SOILN) avulla arvioitiin muutoksia maasta mitatuissa mineraalityppimäärissä sekä typen huuhtoutumassa vuosina 2000-2005. Tutkimuksessa mukana olleet kaksitoista peltolohkoa sijaitsivat neljällä eri tuotantosuuntaa (viljanviljely, luonnonmukainen viljanviljely, sikatalous ja nautakarjatalous) edustavalla tilalla. Mallinnus perustui lohkojen mitattuihin mineraalityppipitoisuuksiin ja haastatteluaineistoon viljelijöiden lohkoilla tekemistä toimenpiteistä. Mineraalitypen huuhtouma oli pienintä viljanviljelytilan lohkoilta, joilla myös keskimääräinen typpitase oli alhaisin. Alhaisempi typpitase vähensi kes- kimääräistä mallinnettua mineraalitypen huuhtoumaa mutta samalla myös mallinnettua kasvien typenottoa. Sika- ja nautakarjatilojen peltolohkoilta simuloitua suurempaa mineraalitypen huuhtoumaa voitiin vähentää pienentämällä lohkojen typpitasetta eli vähentämällä lannoitusta, mutta myös siirtämällä simuloitu karjanlannan levitys pelloille syksystä kevääseen. Jälkimmäinen menettely ei vaikuttanut kasvien simuloituun typenottoon. Luomutilan peltolohkojen typpitaseet ja mineraalitypen huuhtouma olivat samaa luokkaa kuin muilla tiloilla, vaikka luomutilan lannoitustasot olivat selvästi alhaisemmat. Typpitase vaikutti olevan kohtuullisen hyvä indikaattori mineraalitypen huuhtoumalle, kun tarkasteltiin useampien vuosien keskiarvoa. Yhden yksittäisen vuoden huuhtouma riippui paljon myös sadannasta ja lohkolla tehdyistä toimenpiteistä. Keskimäärin vuosittaisen typpitaseen aleneminen $1 \mathrm{~kg} \mathrm{ha}^{-1}$ vähensi typen huuhtoutumista $0.32 \mathrm{~kg} \mathrm{ha}^{-1}$. Suuri typpitase johti mineraalitypen kertymiseen maaperään, josta se helposti huuhtoutui sateisina vuodenaikoina. 